\title{
Size structure and sinking rates of various microparticulate constituents in oligotrophic Hawaiian waters
}

\author{
Paul K. Bienfang \\ The Oceanic Institute, Makapuu Point, Waimanalo, Hawaii 96795, USA
}

\begin{abstract}
In subtropical Hawaiian waters, about $80 \%$ of total chlorophyll and about $60 \%$ of C, N, P, and $\mathrm{Si}$ occur in the $<5 \mu \mathrm{m}$ fraction. This predominance of chlorophyll in the $<5 \mu \mathrm{m}$ fraction prevails throughout the photic zone in extensive areas of the North Central Pacific Ocean. Sinking rates of various constituents reveal vertical, size-related, and day:night differences. In the deep chlorophyll layer, sinking rates were lower than those in the upper mixed layer. Flux estimates indicated that sedimentation accounted for about $7 \%$ of daily photosynthetic carbon production, and that particles $>20 \mu \mathrm{m}$ accounted for most of the microparticulate C, N, P, and Si flux. Calculations showed that constituent turnover rates from sedimentary loss alone are $<1 \%$ of other biological rate processes influencing the concentrations of these constituents (e.g. growth rate). These findings indicate that sedimentation losses from the photic zone resulting from the sinking of intact phytoplankton and/or suspended microparticulates are of comparatively minor importance to the time-dependent changes of phytoplankton biomass in subtropical waters.
\end{abstract}

\section{INTRODUCTION}

Oligotrophic waters represent some of the most extensive yet least understood oceanic ecosystems in the world. Persistent stratification constrains the vertical supply of essential plant nutrients to the photic zone (Dugdale 1967, Eppley et al. 1973). This results in low ambient nutrient concentrations, and resident phytoplankton consequently depend largely on regenerated nutrients. The predominance of small cells in the phytoplankton biomass distinguishes oligotrophic environments (Beers et al. 1975, Fryxell et al. 1979, Bienfang \& Szyper 1981, Platt et al. 1983, Takahashi \& Bienfang 1983). The quantitative importance of both regenerated nutrients and small autotrophs suggests that the sedimentation loss of suspended microparticulate material from the photic zone (= 'new' production) would be low (Eppley \& Peterson 1979). There have been very few observations of sedimentation rates in oligotrophic waters. Bienfang (1980b) measured vertical variations of photosynthetically-active particulates in 2 size fractions, and there are some sediment trap data (Honjo 1978, Knauer et al. 1979, Lorenzen et al. 1983).

(c) Inter-Research/Printed in F. R. Germany
To date, there is no information descriptive of the size structure and settling rates of the various chemical constituents of suspended microparticulate matter in subtropical waters. In this paper, the term 'suspended microparticulates' refers to the particulate material collected using conventional Niskin samplers; Karl \& Knauer (1984) use the term suspended particulate organic carbon (S-POC)' when referring to the carbon content of this material. The purpose of this work was to describe the size structure, sinking rates and flux values of various chemical constituents of the suspended microparticulates, and to examine their vertical, diurnal, and size-related variability. Work was conducted leeward of Oahu, Hawaii, in an area that was previously the focus of an intensive survey (Bienfang et al. 1984b). Phytoplankton populations in the region are nutrient-limited, have low standing stocks, and temporal changes in primary productivity are related to variations in the physical system. This area is in the trade wind zone of the subtropical Pacific, where seasonal changes in oceanic properties are relatively small. The water column has persistently low nutrients in the surface, a deep chlorophyll maximum $(z=90 \mathrm{~m})$, and a deep (i.e. $150 \mathrm{~m}$ ) photic zone. 


\section{MATERIALS AND METHODS}

Sinking rates were measured over 3 cruises (Aug 1982, Jan 1983, Jun 1983) aboard RV 'Kana Keoki'. All 3 cruises examined a station $\left(21^{\circ} 20^{\prime} \mathrm{N}, 158^{\circ} 13^{\prime} \mathrm{W}\right)$ located about $10 \mathrm{~km}$ off the leeward coast of Oahu, Hawaii. Chlorophyll size-structure information (from stations between $18^{\circ} \mathrm{N} 153^{\circ} \mathrm{W}$ and $6^{\circ} \mathrm{S} 153^{\circ} \mathrm{W}$ ) was collected during a cruise in January 1982. Water samples were collected with 12 and 30 I Niskin samplers. The size structure of particulate chlorophyll, carbon $(\mathrm{pC})$, nitrogen $(\mathrm{pN})$, phosphorus $(\mathrm{pP})$, and silica $(\mathrm{pSi})$ were determined by filtrations through Nuclepore polycarbonate filters $(0.4,3,5$, and $10 \mu \mathrm{m}$ pore sizes) and Nitex screens $(20,35$, and $100 \mu \mathrm{m}$ pore sizes). Gravity pressure alone was used for all filtrations involving pore sizes $>0.4 \mu \mathrm{m}$, and triplicate determinations were made for each size interval. The percent concentration occurring above a given pore size was calculated by comparison with total concentration data given by filtrations using $0.4 \mu \mathrm{m}$ Nuclepore filters. Previous works involving microscopic examination of material retained by filters of various pore sizes have shown that such fractionation procedures adequately describe particle size structure, and separate particulates into size classes avallable to suspension-feeding herbivores (Runge \& Ohman 1982, Takahashi \& Bienfang 1983). The $>20 \mu m$ material was collected with an opening-closing net (20 $\mu \mathrm{m}$ mesh) pulled through the water at $5 \mathrm{~m} \mathrm{~min}^{-1}$. Daytime samples were taken at $1000 \mathrm{~h}$ and night-time samples were taken at $2200 \mathrm{~h}$.

The homogeneous sample approach (Bienfang et al. 1977) called SETCOL (Bienfang 1981a) was used for sinking rate measurements. For use at sea, the SETCOL was mounted on a 2-dimensional gimble which was vibration-dampened to attenuate ship motion and propeller beat. The columns were surrounded by a thermostatically-controlled water jacket to maintain a hydrostatic environment. All samples were prescreened through $202 \mu \mathrm{m}$ mesh to remove large zooplankton whose mobility could compromise hydrostatic conditions. Triplicate standing-stock determinations of each biomass parameter under inspection were made both at the beginning and end of each sinking rate trial. These determinations were made to evaluate any biomass changes caused by processes other than sinking. In no cases were the means of the biomass levels before and after the trial significantly $(p>0.05)$

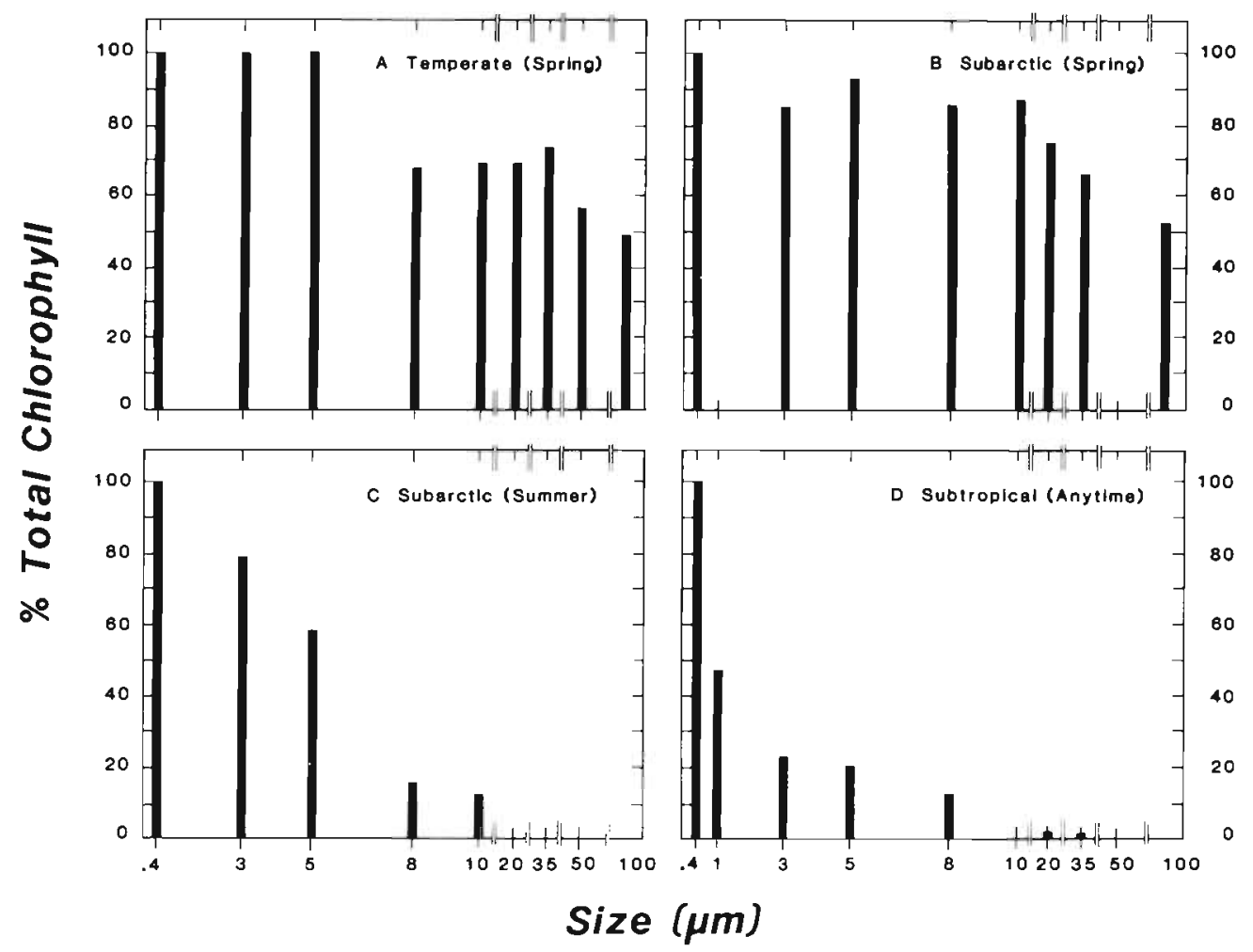

Fig. 1. Chlorophyll size structure in several marine environments. Plots illustrate the percentage of total chlorophyll represented by various size fractions of natural phytoplankton assemblages from (A) temperate (spring); (B) and (C) subarctic (spring and summer); (D) subtropical ecosystems. Samples representing temperate waters were collectec from Washington State, adjacent the Friday Harbor Laboratory; subarctic samples, from Resurrection Bay. Alaska; subtropical samples, from waters off Hawaii Values indicate percentage of total biomass greater than various pore sizes and are based on triplicate analyses in each case ( $c V \leq 15 \%)$ 
different. Chlorophyll was measured according to the fluorometric methods for extracted samples (Strickland \& Parsons 1972). The procedures of Solorzano \& Sharp (1980) and Paasche (1980) were used to measure pP and $\mathrm{pSi}$ while $\mathrm{pC}$ and $\mathrm{pN}$ were measured by gas chromatographic analyses (Sharp 1974).

\section{RESULTS AND DISCUSSION}

\section{Particulate size structure}

Fig. 1 contrasts the size structure of chlorophyll in subtropical Hawaiian waters (Fig. 1 D) with those found in other marine environments. Most of the total population chlorophyll in subtropical seas occurs in the $<5 \mu \mathrm{m}$ fraction, which consists primarily of small flagellates and coccoid cells (Takahashi \& Bienfang 1983). This size distribution is very different from those found in temperate waters (Fig. $1 \mathrm{~A}$ ) or in a subarctic fjord (Fig. $1 \mathrm{~A}$ ) during spring when populations are mostly comprised of large centric diatoms (Bienfang 1984, Bienfang \& Harrison 1984). Other works have shown that the size structure depicted in Figure $1 \mathrm{D}$ prevails in Hawaiian waters (Bienfang \& Szyper 1981, Bienfang et al, 1984a). Fig. 2 presents data taken from both the surface and $100 \mathrm{~m}$ depth (near the chlorophyll
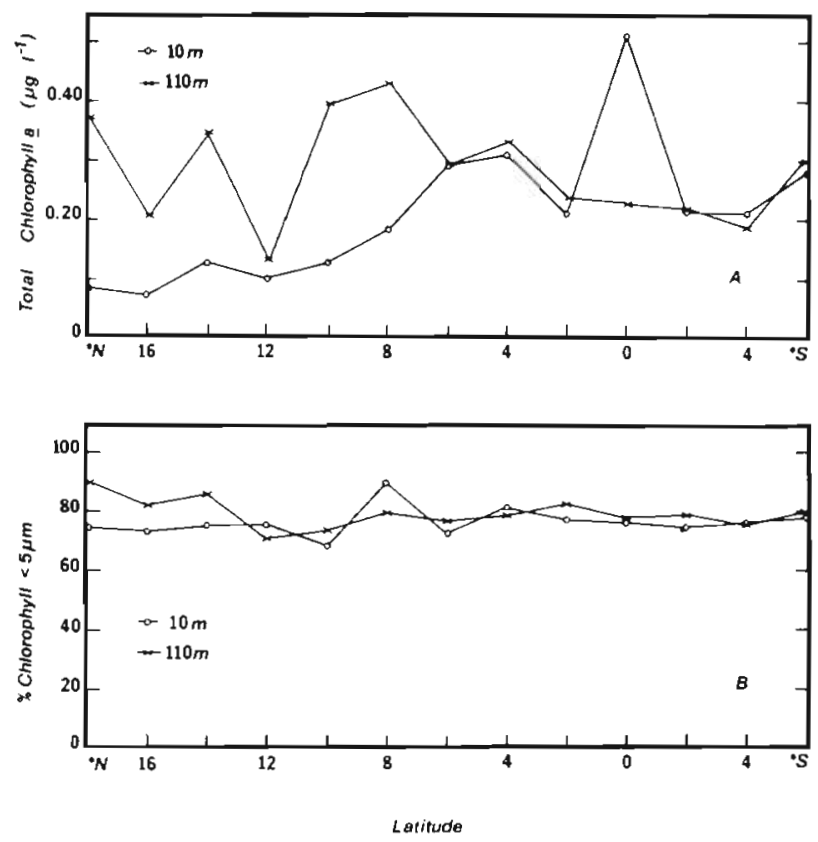

Fig. 2. Chorophyll size distribution across the Central Pacific Ocean. (A) Total chlorophyll concentrations at surface (10 m) and near deep chlorophyll maximum $(110 \mathrm{~m})$ at 13 stations between $18^{\circ} \mathrm{N} 153^{\circ} \mathrm{W}$ and $6^{\circ} \mathrm{S} 153^{\circ} \mathrm{W}$; means of triplicate analyses ( $C v \leq 15 \%$ ). (B) Percentage of total chlorophyll in the $<5 \mu \mathrm{m}$ fraction, indicating predominance of this size fraction throughout the photic zone over an extensive range of subtropical and tropical waters maximum) at 13 stations between $18^{\circ} \mathrm{N} 153^{\circ} \mathrm{W}$ and $6^{\circ} \mathrm{S}$ $153^{\circ} \mathrm{W}$. These data show that about $80 \%$ of total chlorophyll occurs in cells $<5 \mu \mathrm{m}$ throughout the photic zone and over extensive areas of the Pacific. The persistence of small-celled phytoplankton biomass appears to be a signature of warm, well-stratified oligotrophic ecosystems where low ambient nutrient levels prevail. The high surface area:volume ratio of small cells promotes diffusive nutrient uptake, which together with reduced sinking losses, are advantageous mechanisms in low nutrient environments. The change in phytoplankton size structure in the subarctic coastal environment (Fig. 1 B, C) coincided with changes in the nutrient field (Bienfang 1984). In summer, when stratification restricts vertical nutrient supply and phytoplankton uptake and sinking depletes ambient nutrients, the population size structure shifts to a pattern similar to that observed in permanently stratified subtropical waters (Fig. 1 D).

Other microparticulate constituents display size distributions similar to that of chlorophyll, although the decrease in concentration with increasing size is less pronounced (Table 1). In subtropical waters, 57 to $66 \%$ of the $\mathrm{pC}, \mathrm{pN}$, and $\mathrm{pP}$ occurs in the $<5 \mu \mathrm{m}$ fraction. In the subarctic or the temperate environments, the total concentrations of $\mathrm{pC}, \mathrm{pN}, \mathrm{pP}$, and $\mathrm{pS}$ are much higher and relative contributions are at a size threshold considerably greater than that found in subtropical waters. Together these data illustrate that the total concentration of various particulate constituents in oligotrophic waters is not only lower but occurs in particles of generally smaller size than those found in higher latitude systems.

\section{Sinking rates}

Fig. 3 presents the mean sinking rates and standard deviations of the various chemical constituents for several size classes of particulates. The mean values represent ensemble averages of samples collected over the year at various times of day and at various depths throughout the photic zone. Mean sinking rates of total $(>0.4 \mu \mathrm{m})$ particulates were low overall, ranging from $0.06 \pm 0.02 \mathrm{~m} \mathrm{~d}^{-1}$ for chlorophyll to $0.23 \pm 0.08 \mathrm{~m} \mathrm{~d}^{-1}$ for silica. Size-related differences in the sinking rates of all constituents are evident. A systematic increase in sinking rate with increasing particle size is particularly apparent for rates based on chlorophyll. A higher chlorophyll quota for the predominant small-celled phytoplankton lowers the sinking rate value calculated on the basis of this constituent. Average sinking rates for the $>20 \mu \mathrm{m}$ fraction with respect to all constituents were distinctly higher than rates for total particulates; the degree of difference was most pronounced for chlorophyll $\left(\psi>20 \mu \mathrm{m} / \psi_{>04 \mu \mathrm{m}}=7 \times\right)$ and 
Table 1. Size structure of particulate $C, N, P$, and $\mathrm{Si}$ in 3 marine environments. Data give average concentration values $\left(\mu g \mathrm{l}^{-1}\right)$ and percent of total concentrations due to particulates greater than the various size thresholds. Standard deviations based on triplicate analyses except for the $0.4 \mu \mathrm{m} \mathrm{C}$ and $\mathrm{N}$ data where $\mathrm{n}=36$

\begin{tabular}{|c|c|c|c|c|c|c|c|c|}
\hline \multirow[t]{3}{*}{ Ecosystem } & \multirow[t]{3}{*}{ Season } & \multirow{3}{*}{$\begin{array}{c}\text { Size } \\
\text { fraction } \\
(\mu \mathrm{m})\end{array}$} & \multicolumn{6}{|c|}{ Particulate parameters $\left(\mu \mathrm{g} \mathrm{l}^{-1}\right)$} \\
\hline & & & & Carbon & & & itrogen & \\
\hline & & & Mean & SD & $\%$ & Mean & $\mathrm{SD}$ & $\%$ \\
\hline \multirow[t]{4}{*}{ Subtropical } & \multirow[t]{4}{*}{ Anytime } & 0.4 & 54.78 & 9.45 & 100 & 7.69 & 2.55 & 100 \\
\hline & & 5 & 35.33 & 0.74 & 65 & 4.34 & 0.13 & 57 \\
\hline & & 10 & 23.32 & 1.72 & 42 & 4.28 & 0.22 & 56 \\
\hline & & 20 & 10.96 & 1.89 & 20 & 1.54 & 0.41 & 20 \\
\hline \multirow[t]{4}{*}{ Subartic } & \multirow[t]{4}{*}{ Summer } & 0.4 & 491.50 & 34.80 & 100 & 55.90 & 4.50 & 100 \\
\hline & & 8 & 153.40 & 2.50 & 31 & 17.40 & 0.60 & 31 \\
\hline & & 20 & 325.60 & 4.90 & 66 & 33.00 & 0.70 & 59 \\
\hline & & 35 & 216.40 & 38.70 & 44 & 15.70 & 1.00 & 28 \\
\hline \multirow[t]{6}{*}{ Temperate } & \multirow[t]{6}{*}{ Spring } & 0.4 & 359.60 & 10.40 & 100 & 44.80 & 4.30 & 100 \\
\hline & & 5 & 360.50 & 30.10 & 100 & 42.60 & 1.80 & 95 \\
\hline & & 10 & 289.30 & 22.50 & 80 & 36.90 & 2.70 & 82 \\
\hline & & 20 & 274.70 & 7.50 & 76 & 32.40 & 4.30 & 72 \\
\hline & & 100 & 105.00 & 6.50 & 29 & 13.70 & 0.60 & 30 \\
\hline & & & \multicolumn{3}{|c|}{ Phosphorus } & \multicolumn{3}{|c|}{ Silica } \\
\hline \multirow[t]{4}{*}{ Subtropical } & \multirow[t]{4}{*}{ Anytime } & 0.4 & 0.42 & 0.028 & 100 & 2.61 & 1.04 & 100 \\
\hline & & 5 & 0.28 & 0.050 & 66 & - & - & - \\
\hline & & 10 & - & - & - & 1.11 & 0.13 & 42 \\
\hline & & 20 & 0.11 & 0.01 & 25 & 0.57 & 0.13 & 22 \\
\hline \multirow[t]{4}{*}{ Subartic } & \multirow[t]{4}{*}{ Summer } & 0.4 & 9.34 & 1.99 & 100 & 56.50 & 6.00 & 100 \\
\hline & & 8 & 2.99 & 0.03 & 32 & 31.00 & 9.50 & 55 \\
\hline & & 20 & 1.72 & - & 18 & 28.30 & 2.40 & 50 \\
\hline & & 35 & 1.16 & 0.22 & 12 & 7.60 & 5.50 & 13 \\
\hline \multirow[t]{5}{*}{ Temperate } & \multirow[t]{5}{*}{ Spring } & 0.4 & 106.40 & 26.00 & 100 & 243.40 & 3.20 & 100 \\
\hline & & 5 & 63.20 & 5.70 & 59 & 221.60 & 0.20 & 91 \\
\hline & & 10 & 69.20 & 36.80 & 65 & 235.00 & 0.00 & 97 \\
\hline & & 20 & 63.40 & 12.20 & 60 & 57.50 & 17.20 & 24 \\
\hline & & 100 & 12.70 & 2.70 & 12 & 26.50 & 14.30 & 11 \\
\hline
\end{tabular}

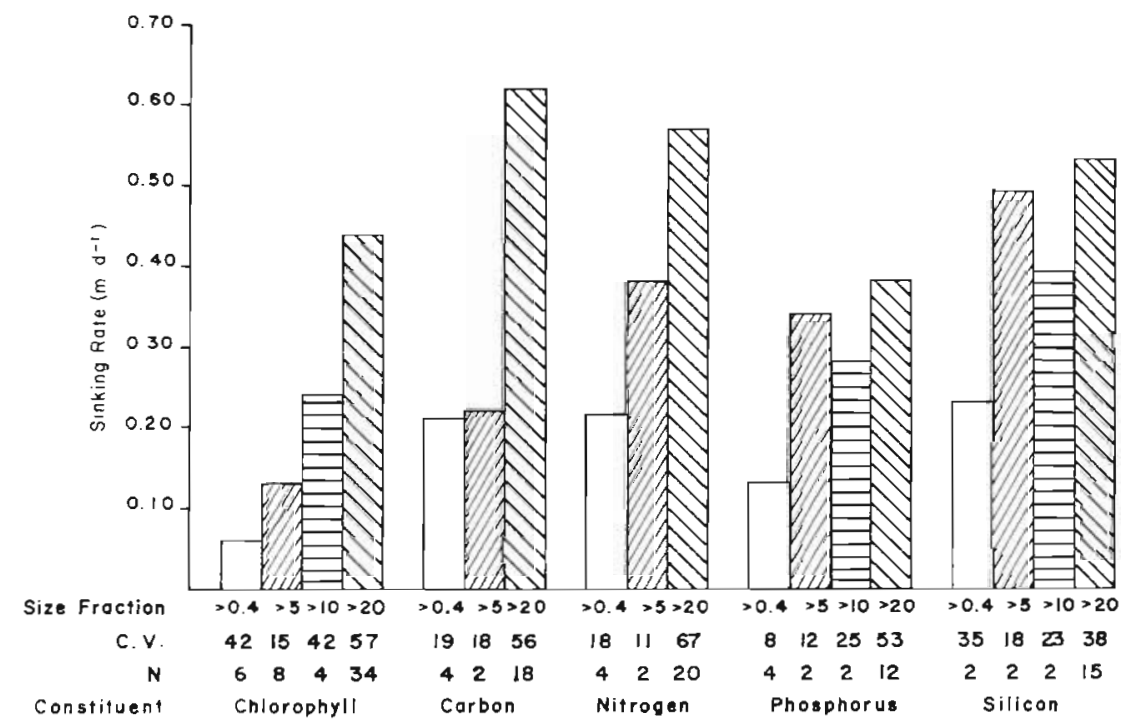

Fig. 3. Summary of size-related sinking rate differences for various constituents of suspended microparticulates in subtropical ocean waters. Mean values represent ensemble averages of samples collected throughout the year at various times of day and at various depths throughout the photic zone. Coefficient of variation (c.v.) is based on $\mathrm{N}$ determinations and embraces vertical, temporal, and analytical variability 
ranged between 2 and $3 \times$ for the other parameters examined. The floristic composition of phytoplankton in the $>20 \mu \mathrm{m}$ fraction was dinoflagellates $>$ coccolithophorids $>$ diatoms on the basis of numerical abundance. Pennate diatoms outnumbered centrics by ca 3:1; other studies (Bienfang \& Harrison 1984) have indicated that pennate diatoms have generally lower sinking rates than centric forms. The most common genera for the dinoflagellates were Peridinium spp. and Prorocentrum spp.; for the coccolithophorids, Discosphaera spp.; and for the pennate diatoms, Navicula spp. and Nitzschia spp.

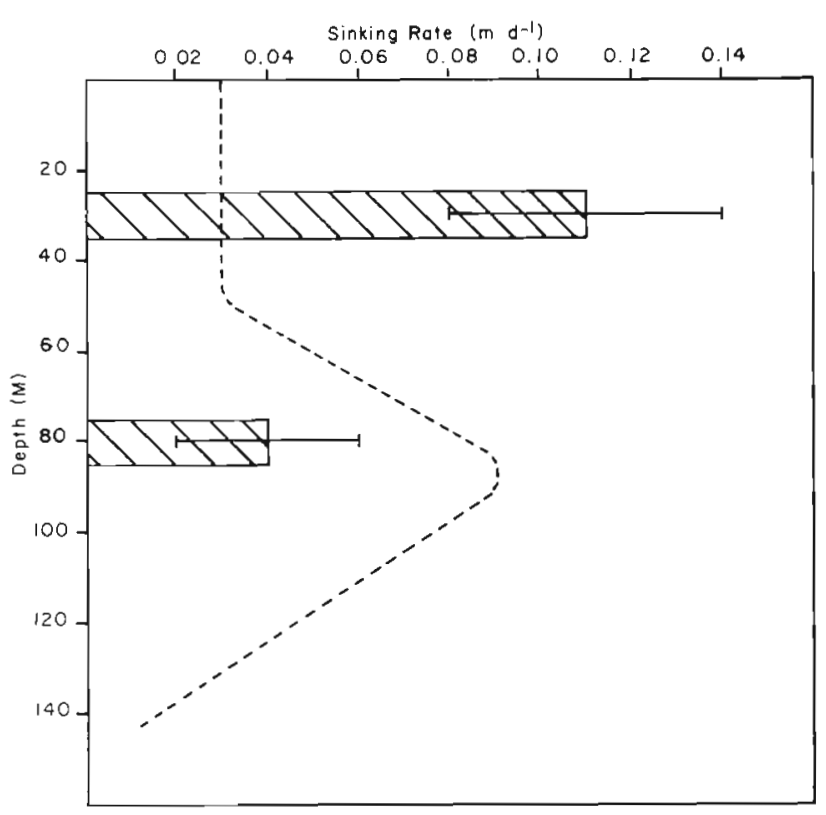

Fig. 4. Variation in sinking rate of total particulate chlorophyll between upper mixed layer and subsurface chlorophyll maximum layer. All samples collected during the day. Mixed layer samples $(n=6)$ came from 20,30 and $50 \mathrm{~m}$; deep samples $(n=4)$, from $80 \mathrm{~m}$. Error bars: standard deviation; dashed line: qualitative vertical chlorophyll distribution typical of the area
Vertical differences in sinking rates were also apparent. Fig. 4 illustrates a comparison of the mean sinking rates of total particulate chlorophyll found in samples from the upper mixed layer $(z=10$ to $50 \mathrm{~m}$ ) and from the region near the deep chlorophyll maximum $(z=90 \mathrm{~m})$. These results indicate that sinking rates in these 2 areas differ by more than a factor of 2 . The lower sinking rates in the region of the chlorophyll maximum are consistent with findings from a study of larger particulates conducted in another subtropical locale (Bienfang 1980b), using a method which focused only on the photosynthetically-active components of the population. As explained in Bienfang et al. (1983). in subtropical waters, the appearance of reduced sinking rates in this layer is thought to coincide with rather than cause the increased chlorophyll concentrations. Observation indicates physiological adjustments to the region do produce lower sinking rates, but, given the prevailing particle size structure and the degree of chlorophyll increases common in such areas, shadeadaptation alone can account for the subsurface chlorophyll maximum in oligotrophic waters (Venrick et al. 1973, Kiefer et al. 1976, Bienfang et al. 1983).

Day:night differences were evident in the sinking rates of the various constituents in the $>20 \mu \mathrm{m}$ fraction (Fig. 5). For chlorophyll, day:night differences appeared in samples taken from both the 0 to $100 \mathrm{~m}$ and 100 to $200 \mathrm{~m}$ depth interval. Other analyses, based on separate sampling over the 0 to $150 \mathrm{~m}$ range, also indicated higher sinking rates for the different constituents during the evening period. Only particulate phosphorus failed to show appreciable day:night differences in sinking rate. Data from all constituents, depth intervals, and samplings suggest that sinking rates in the evening were about twice what was measured during the day in this subtropical system. In the field samples, the nature of diumal sinking rate variability parallels that observed in laboratory cultures (Eppley et al. 1967a, b, Boleyn 1972, Smayda 1975,
Fig. 5. Day:night differences in sinking rates of various constituents in the $>20 \mu \mathrm{m}$ fraction of suspended particulate material in subtropical Hawaiian waters. Samples collected by net tows over the depth range indicated. Error bars: standard deviation for $\mathrm{n}=4$ replicate determinations in each case

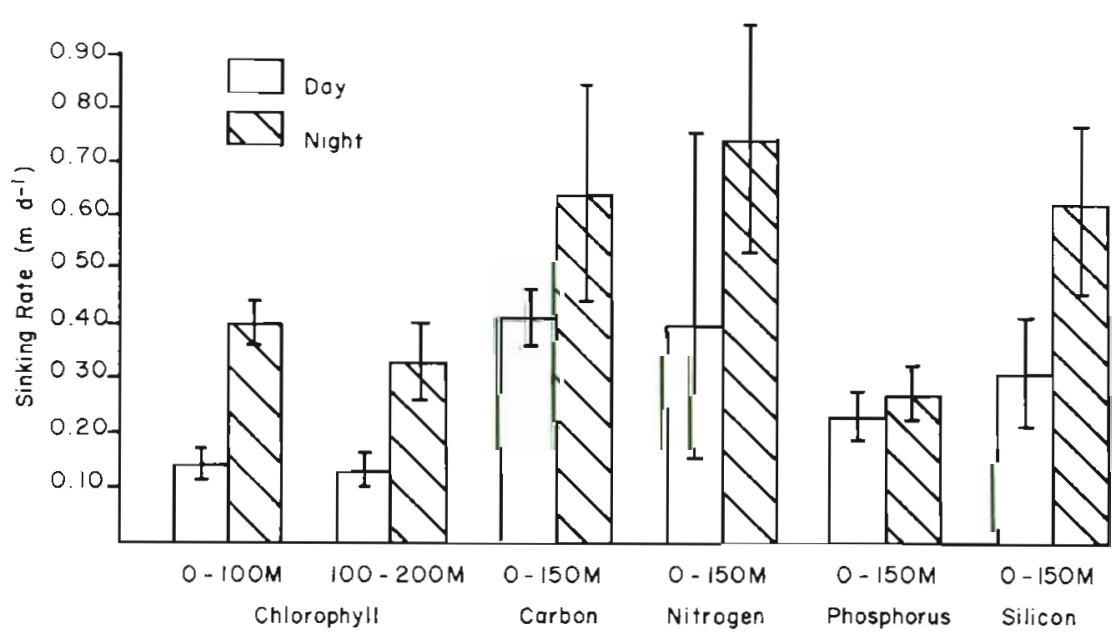


Bienfang 1981b). Such diurnal variability suggests a close association of the energy-requiring mechanism of buoyancy regulation with photosynthetic activity.

\section{Microparticulate fluxes}

Table 2 summarizes the downward flux $(F)$ calculated for various constituents of the suspended microparticulates in subtropical waters. $F$ values are the products of the concentration $(B)$ and sinking rate $(\psi)$ values. The $B$ and $\psi$ values listed represent ensemble averages from samplings at a variety of times and depths throughout the photic zone, and are used to describe the system's general synoptic condition. Note that all analyses are based on discrete samples, and it is therefore improbable that the particulate material collected would include large particles (e.g. fecal pellets, marine snow, or large aggregates which are not numerically abundant). The implication of sediment trap studies (McCave 1975, Stephens et al. 1976, Honjo 1978, Knauer et al. 1979) is that such particles, despite their low abundance, are important contributors to total particulate flux, especially deep in the ocean. The sinking rates of fecal pellets are 2 to 3 orders of magnitude greater than these rates for microparticulates (Smayda 1969, 1971, Fowler \& Small 1972, Turner 1977, Honjo \& Roman 1978, Small et al. 1979, Bienfang 1980 a). The term 'total microparticulates', as used here, is operationally defined to mean the particulates collected by discrete samples.

Some useful information can be derived from these results. First, Table 2 contains flux estimates for a variety of particulate constituents (e.g. pC, pN, pP,pSi) which have both ecological and geochemical importance. Small particles constitute most of the suspended particulate material (McCave 1975, Honjo 1978) in such systems. The flux estimates for these elements have a wide range; carbon is highest $\left(11.50 \mathrm{mg} \mathrm{C} \mathrm{m}^{-2}\right.$ $\left.\mathrm{d}^{-1}\right)$ and phosphorus lowest $\left(0.055 \mathrm{mg} P \mathrm{~m}^{-2} \mathrm{~d}^{-1}\right)$. The C:N:Si:P ratio of the microparticulate fluxes is 209:31:11:1 (by weight) and 544:69:12:1 (by atoms). The higher value for carbon is caused partly by the substantial content of detrital carbon in the total particulate material, and reflects the high degree of reingestion and regeneration of suspended particulate material occurring in subtropical ecosystems. Carbon flux estimates for subtropical Hawaiian waters have recently been collected using floating sediment trap arrays which would include contributions of large particulates (Lorenzen et al. 1983). The flux estimates found for carbon were also much higher than those for chlorophyll, and indicated that a comparatively small fraction of the sedimentary $\mathrm{pC}$ was recently associated with phytoplankton. Comparison of the carbon flux value from this study $\left(F c=11.5 \mathrm{mg} \mathrm{C} \mathrm{m}^{-2} \mathrm{~d}^{-1}\right.$ ) with Lorenzen et al.'s (1983) value using sediment traps ( $F \mathrm{C}=55.9 \mathrm{mg} \mathrm{C} \mathrm{m} \mathrm{m}^{-2} \mathrm{~d}^{-1}$ ) suggests that about $21 \%$ of the total carbon flux is due to the type of suspended microparticulate material collected via Niskin samplings.

Secondly, chlorophyll flux is very low, probably because of the size structure of phytoplankton in oligotrophic ecosystems (Fig. 1 \& 2). Nearly all the chlorophyll is present in very small cells which have negligible settling rates, so very little sedimentary loss

Table 2. Summary of sinking rate and flux data for various constituents in 2 size classes of particulate material in an oligotrophic ecosystem. Concentration $(B)$ and sinking rate $(\psi)$ data are averages from samples taken at various times and depths throughout the photic zone. Calculated flux $(F)$ is the product of $B \times \psi_{i} F^{\prime}$ gives the percentage of total flux due to particles $>20 \mu m\left[F^{\prime}=100\right.$ $\left.\left(F_{>20 \mu \mathrm{m}} / F_{>0.4 \mu \mathrm{m}}\right)\right]$. The term $\mathrm{B}^{*}$ gives depth-integrated values for the photic zone where the limits of integration are $z=0$ to $150 \mathrm{~m}$. Turnover time $(\mathrm{t})$ based only on direct sedimentation of microparticulates is given by $t=F / B^{*}$

\begin{tabular}{|c|c|c|c|c|c|}
\hline \multirow[t]{2}{*}{ Size fraction } & \multicolumn{5}{|c|}{ Constituent } \\
\hline & Chlorophyll & Carbon & Nitrogen & Phosphorus & Silica \\
\hline \multicolumn{6}{|l|}{$>0.4 \mu \mathrm{m}$} \\
\hline$B\left(\mathrm{mg} \mathrm{m}^{-3}\right)$ & 0.11 & 54.78 & 7.69 & 0.421 & 2.610 \\
\hline$\psi\left(m^{-1}\right)$ & 0.06 & 0.21 & 0.22 & 0.13 & 0.23 \\
\hline $\mathrm{F}\left(\mathrm{mg} \mathrm{m}^{-2} \mathrm{~d}^{-1}\right)$ & 0.0066 & 11.50 & 1.69 & 0.055 & 0.600 \\
\hline$B^{-}\left(\mathrm{mg} \mathrm{m}^{-2}\right)$ & 19.90 & 8217 & 1154 & 63.2 & 391.5 \\
\hline$t\left(d^{-1}\right)$ & .0003 & .0014 & .0015 & .0009 & .0015 \\
\hline \multicolumn{6}{|l|}{$>20 \mu \mathrm{m}$} \\
\hline $\mathrm{B}\left(\mathrm{mg} \mathrm{m}^{-3}\right)$ & 0.0033 & 10.956 & 1.538 & 0.084 & 0.522 \\
\hline$\psi\left(\mathrm{m} \mathrm{d}^{-1}\right)$ & 0.44 & 0.55 & 0.57 & 0.38 & 0.57 \\
\hline$F\left(\mathrm{mg} \mathrm{m}^{-2} \mathrm{~d}^{-1}\right)$ & 0.0015 & 6.026 & 0.877 & 0.032 & 0.277 \\
\hline$F^{\prime}(\%)$ & 22 & 52 & 52 & 58 & 46 \\
\hline $\mathrm{B}^{\cdot}\left(\mathrm{mg} \mathrm{m} \mathrm{m}^{-2}\right)$ & 0.60 & 1643 & 230.8 & 12.64 & 78.30 \\
\hline$t\left(d^{-1}\right)$ & .0025 & .0037 & .0038 & .0025 & .0035 \\
\hline
\end{tabular}


of phytoplankton directly results from sinking. Third, the proportion of total flux due to larger (i.e. $>20 \mu \mathrm{m}$ ) particles can be calculated from the flux data for both total microparticulates and the $>20 \mu \mathrm{m}$ fraction. The relative amount of total flux attributable to particles in the $>20 \mu \mathrm{m}$ fraction was similar for most constituents ( $\mathrm{pC}, \mathrm{pN}, \mathrm{pP}, \mathrm{pSi}$ ) and ranged from 46 to $58 \%$; the low value $(22 \%)$ for chlorophyll results from the very low chlorophyll concentrations in the $>20 \mu \mathrm{m}$ fraction.

Fourth, the photosynthesis and carbon flux data can be used to generate estimates of the percentage of daily primary production leaving the subtropical photic zone via sedimentation. Annual primary production in this area is $60.4 \mathrm{~g} \mathrm{C} \mathrm{m}^{-2}$ (Bienfang et al. $1984 \mathrm{~b}$ ). Given the average sinking flux value for carbon

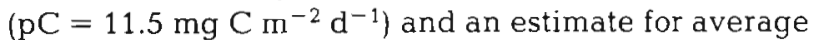
photosynthesis ( $\left.165.5 \mathrm{mg} \mathrm{C} \mathrm{m}^{-2} \mathrm{~d}^{-1}\right)$, I estimate that about $7 \%$ of daily primary production is lost as a result of the sinking of microparticulate material. This percentage is in general agreement with percentage values calculated from sediment trap data collected in subtropical waters (Eppley \& Peterson 1979, Lorenzen et al. 1983).

Comparison of the SETCOL results with those of Lorenzen et al. (1983) also reveals an inconsistency: (a) similar values for the percentage of total carbon production represented by sedimentary loss, but (b) carbon flux values for suspended microparticulates (i.e. SETCOL results) about a fifth those for total particulates (i.e. sediment trap results). For both (a) and (b) to be true would imply that, in this system, total carbon flux is about $33 \%$ (i.e. $0.07 / 0.21$ ) of total primary production; this is an inordinately high fraction for an oligotrophic area. There are two possible explanations for the apparent contradiction: either the primary production value used by Lorenzen et al. is higher than the one used here or the $7 \%$ value derived in this work overestimates the actual carbon flux out of the photic zone which is due to suspended microparticulate material. First, the Lorenzen et al. (1983) study does not give a value for total primary production applied. For the carbon flux estimate $\left(55.9 \mathrm{mg} \mathrm{C} \mathrm{m}^{-2} \mathrm{~d}^{-1}\right.$ ) to be 10 to $15 \%$ (Lorenzen pers. comm.) of total primary production would require a daily integrated carbon production of 375 to $550 \mathrm{mg} \mathrm{C} \mathrm{m}^{-2} \mathrm{~d}^{-1}$, which is considerably greater than the value for photosynthetic carbon production (Bienfang et al. 1984b) which was used to derive the $7 \%$ value in this study. The increased carbon production might be due to production by components of the microbial community other than the photoautotrophs. Based on nucleic acid synthesis, Winn \& Karl (1984) showed a total microbial production in Hawaiian oceanic waters equivalent to $400 \mathrm{mg} \mathrm{C} \mathrm{m}^{-2}$ $\mathrm{d}^{-1}$. Secondly, the values which led to the $7 \%$ estimate in this work were based on water samples taken from a variety of depths within the photic zone. If the suspended material examined with these samplings was subjected to substantial regeneration/reworking prior to leaving the photic zone, then the $7 \%$ value derived would overestimate the fraction of suspended microparticulate flux which actually exits the photic zone.

Finally, turnover times for the various particulate constituents can be calculated solely on the basis of sedimentation (Table 2 ). The values $B^{*}(x)$ represent the vertically-integrated values, giving total photic zone concentrations for each constituent $(x)$; division of the flux values by the $B^{*}(x)$ values yields turnover rates (t) in units of inverse time. For all constituents, the $t$ values for the $>20 \mu \mathrm{m}$ fraction are considerably larger than those for total microparticulates $(>0.4 \mu \mathrm{m})$. For $\mathrm{pC}, \mathrm{pN}, \mathrm{pP}$, and $\mathrm{pSi}$, the $\mathrm{t}$ values for the $>20 \mu \mathrm{m}$ fraction are about 2 to $3 \times$ those for the $>0.4 \mu \mathrm{m}$ particulates. Considerably larger (about $8 \times$ ) size-related differences are indicated for chlorophyll, despite the small amount of material in the $>20 \mu \mathrm{m}$ fraction. The magnitude of this difference results primarily from the extremely low sinking velocities of the total picoplankton-dominated assemblage. More importantly, the absolute values for turnover rate resulting from sedimentary loss are at least 2 orders of magnitude lower than the biological rate processes (e.g. specific growth rate) which influence concentrations of these constituents. Although sinking may affect the fate and/ or vertical distribution of certain floristic components, the nature of phytoplankton assemblages in oligotrophic ecosystems lends conservative properties to the environment. These values indicate that the sinking of intact phytoplankton from the photic zone in subtropical waters is of comparatively minor importance to the time-dependent changes of photoautotrophic biomass. Another way of expressing this result is to state that the downward flux of (microparticulate) chlorophyll accounts for $0.03 \%$ of the total depth-integrated standing stock, or $0.25 \%$ of the depth-integrated standing stock of the $>20 \mu \mathrm{m}$ fraction. Lorenzen et al. (1983) derived a value of $0.8 \%$; this value represents an upper bound for the relative chlorophyll loss due to sedimentation because their sampling scheme would include ingested/excreted chlorophyll.

The large differences between the calculated $t$ values and rates of other biological processes influencing biomass affect modelling efforts seeking to describe time-dependent changes in the biomass of subtropical assemblages. Models do not need to incorporate a term to account for biomass loss resulting from direct phytoplankton sinking until the precision of such efforts would be influenced by rate processes less than $1 \%$ those of phytoplankton growth. The modest importance of sinking losses is probably unique to subtropi- 
cal environments which display comparatively little climatic, chemical or biological seasonality.

Acknowledgement. This work was supported by NSF Grant No. OCE-8100679-01.

\section{LITERATURE CITED}

Beers, J. R., Reid, T. M. H., Stewart, G. L. (1975). Microplankton of the North Pacific Central gyre. Population structure and abundance. Int. Revue ges. Hydrobiol 60: 607-638

Bienfang, P. K. (1980a). Herbivore diet affects fecal pellet settling. Can. J. Fish. aquat. Sci. 37 (9): 1352-1357

Bienfang, P. K. (1980b). Phytoplankton sinking rates in oligotrophic waters off Hawaii. Mar Biol. 61: 69-77

Bienfang, P. K. (1981a). SETCOL-a technologically simple and reliable method for measuring phytoplankton sinking rates. Can. J. Fish. aquat. Sci. 38 (10): 1289-1294

Bienfang, P. K. (1981b). Sinking rates of heterogeneous temperate phytoplankton populations. J. Plankton Res. 3 (2): 235-253

Bienfang, P. K. (1984). Size structure and sedimentation of biogenic microparticulates in a subarctic ecosystem. $J$ Plankton Res. 6 (6): 985-995

Bienfang, P. K., Harrison, P. J. (1984). Sinking rate response of natural assemblages of temperate and subtropical phytoplankton to nutrient depletion. Mar. Biol. 83: 293-300

Bienfang, P. K., Laws, E. A., Johnson, W. (1977). Phytoplankton sinking rate determination: Technical and theoretical aspects, an improved methodology. J. exp. mar. Biol. Ecol. 30: $283-300$

Bienfang, P. K., Morales, L., Klein, K., Takahashi, M. (1984a). Picoplankton growth rates in subtropical Hawaiian embayments. Pacif. Sci. 38 (2): 134-140

Bienfang, P. K., Szyper, J. P. (1981). Phytoplankton dynamics in the subtropical Pacific Ocean off Hawaii. Deep Sea Res. 28 (9): 981-1000

Bienfang, P. K., Szyper, J. P., Laws, E. A. (1983): Sinking rate and pigment responses to light-limitation by a marine diatom. Implications to dynamics of chlorophyll maximum layers. Oceanologica Acta 6 (1): 55-62

Bienfang, P. K., Szyper, J. P., Okamoto, M., Noda, E. K. (1984b). Temporal and spatial variability of phytoplankton in a subtropical ecosystem. Limnol. Oceanogr. 29 (3): $527-539$

Boleyn, B. J. (1972). Studies on the suspension of the marine centric diatom Ditylum brightwelli (West) Grunow. Int. Revue ges. Hydrobiol. 57: 585-597

Dugdale, R. C. (1967). Nutrient limitation in the sea: dynamics, identification and significance. Limnol. Oceanogr. 12: 196-206

Eppley, R. W., Holmes, R. W., Paasche, E. (1967a). Periodicity in cell division and physiological behavior of Ditylum brightwelli, a marine planktonic diatom, during growth in light-dark cycles. Arch. Mikrobiol. 56 (5): 305-323

Eppley, R. W., Holmes, R. W., Strickland, J. D. H. (1967b). Sinking rates of marine phytoplankton measured with a fluorometer. J. exp. mar. Biol. Ecol. 1. 191-208

Eppley, R. W., Peterson, B. J. (1979). Particulate organic matter flux and planktonic new production in the deep ocean. Nature, Lond. 282: 677-680

Eppley, R. W., Renger, E. H., Venrick, E. L., Mullin, M. M. (1973). A study of plankton dynamics and nutrient cycling in the Central Gyre of the North Pacific Ocean. Limnol. Oceanogr. 18: 534-551

Fowler, S. W., Small, L. F. (1972). Sinking rates of euphausiid fecal pellets. Limnol. Oceanogr. 17: 293-296

Fryxell, G. A., Taguchi, S., El-Sayed, S. Z. (1979). Vertical distribution of diverse phytoplankton communities in the central Pacific. In: Bishop, J. L., Piper, D. Z. (ed.) Marine geology and oceanography of the Pacific manganese nodule province. Plenum Press, New York, p. 203-239

Honjo, S. (1978). Sedimentation of materials in the Sargasso Sea at a 5,367 m deep station. J. mar. Res. 36: 469

Honjo, S., Roman, M. R. (1978). Marine copepod fecal pellets: production, preservation and sedimentation. J. mar. Res. 36: $45-47$

Karl, D. M., Knauer, G. A. (1984). Vertical distribution, transport, and exchange of carbon in the northeast Pacific Ocean: evidence for multiple zones of bioactivity. Deep Sea Res. 31 (3): 221-243

Kiefer, D. A., Olson, R. H., Holm-Hansen, O. (1976). Another look at the nitrite and chlorophyll maxima in the central North Pacific. Deep Sea Res. 23: 1199-1209

Knauer, G. A., Martin, J. H., Bruland, K. W. (1979). Fluxes of particulate carbon, nitrogen and phosphorus in the upper water column of the northeast Pacific. Deep Sea Res. 26: $97-108$

Lorenzen, C. J., Welschmeyer, N. A., Copping, A. E., Vernet, M. (1983). Sinking rates of organic particles. Limnol. Oceanogr. 28 (4): 766-769

McCave, I. N. (1975). Vertical flux of particles in the ocean. Deep Sea Res. 22: 491-502

Paasche, E. (1980). Silicon content of fine marine plankton diatom species measured with a rapid filter method. Limnol. Oceanogr. 25: 474-480

Platt, T., Subba-Rao, D. V., Irvin, B. (1983). Photosynthesis by picoplankton in the oligotrophic ocean. Nature, Lond. 30 : 702-704

Runge, J. A., Ohman, M. D. (1982). Size fractionation of phytoplankton as an estimate of food available to herbivores. Limnol. Oceanogr. 27: 570-576

Sharp, J. H. (1974). Improved analysis for 'particulate' organic carbon and nitrogen from seawater. Limnol. Oceanogr. 19: 984-989

Small, L. F., Fowler, S. W., Unlu, M. Y. (1979). Sinking rates of natural copepod fecal pellets. Mar. Biol. 51: 233-241

Smayda, T J. (1969). Some measurements of the sinking rate of fecal pellets. Limnol. Oceanogr. 14: 621-625

Smayda, T. J. (1971). Normal and accelerated sinking of phytoplankton in the sea. Mar. Geol. 11: 105-122

Smayda, T. J. (1975). Phased cell division in natural populations of the marine diatom Ditylum brightwelli and the potential significance of diel phytoplankton behavior in the sea. Deep Sea Res. 22: 151-165

Solorzano, L., Sharp, J. H. (1980). Determination of total dissolved phosphorus and particulate phosphorus in natural waters. Limnol. Oceanogr. 25: 754-758

Stephens, K., Sheldon, R. W., Parsons, T. R. (1976). Seasonal variation in the availability of food for benthos in a coastal environment. Ecology 48: 852-855

Strickland, J. D. H., Parsons, T. R. (1972). A practical handbook of seawater analysis. Bull. Fish. Res. Bd Can. 167 $1-311$

Takahashi, M., Bienfang, P. K. (1983). Size structure of phytoplankton biomass and photosynthesis in subtropical Hawailan waters. Mar. Biol. 76: 213-218

Turner, J. T (1977). Sinking rates of fecal pellets from marine copepod Pentella meadii. Mar. Biol. 40: 249-259

Venrick, E. L., McGowan, J. A., Mantyla, A. W. (1973). Deep 
maxima of photosynthetic chlorophyll in the Pacific Ocean. Fish. Bull. U. S. 71: 41-51

Wiebe, P. N., Boyd, S. H., Winget, C. J. (1976). Particulate matter sinking to the deep-sea floor at $2000 \mathrm{~m}$ in the
Tongue of the Ocean, Bahamas, with a description of a new sedimentation trap. J. mar. Res. 34: 341

Winn, C. D., Karl, D. M. (1984). Microbial productivity and community growth rate estimates in the tropical North Pacific Ocean. Biol. Oceanogr. 3 (2): 123-145

This paper was submitted to the editor; it was accepted for printing on March 12, 1985 


\title{
Reproductive biology of the deep-sea holothurians Laetmogone violacea and Benthogone rosea (Elasipoda: Holothurioidea)
}

\author{
P. A. Tyler ${ }^{1}$, A. Muirhead ${ }^{1}$, D. S. M. Billett ${ }^{2} \&$ J. D. Gage ${ }^{3}$ \\ ${ }^{1}$ Department of Oceanography, University College, Singleton Park, Swansea SA2 8PP, United Kingdom \\ 2 Institute of Oceanographic Sciences, Brook Road, Wormley, Godalming, Surrey, United Kingdom \\ ${ }^{3}$ Scottish Marine Biological Association. P. O. Box 3, Oban, Argyll, Scotland, United Kingdom
}

\begin{abstract}
Specimens were examined from a number of stations (960 to $2120 \mathrm{~m}$ depth) in the Porcupine Seabight and Rockall Trough, N. E. Atlantic Ocean. Both species are gonochoric and show an equal division of the sexes. The ovary of Laetmogone violacea is a compact nodose structure containing eggs up to $400 \mu \mathrm{m}$ diameter. The testis is highly digitate, with the wall of each tubule containing numerous infoldings lined with spermatogonia and spermatocytes; spermatozoa reach a maximum size of $2 \mu \mathrm{m}$ (head diameter). The ovary of Benthogone rosea consists of thin-walled nodose tubules through which the large egg of $750 \mu \mathrm{m}$ diameter can be clearly seen. The testis of $B$. rosea is a small digitate structure, the walls of which lack the infoldings found in L. violacea; spermatozoa have a head diameter of 5 to $7 \mu \mathrm{m}$. In neither species is there any evidence for reproductive seasonality.
\end{abstract}

\section{INTRODUCTION}

Holothurians comprise a large and conspicuous proportion of the total biomass of the benthic boundary at great depths (Pawson 1966, Filatova 1969, Menzies et al. 1973, Barnes et al. 1976, Khripounoff et al. 1980 Sibuet \& Lawrence 1981). They appear regularly in deep-sea photographs (Heezen \& Hollister 1971) and may be observed occurring singly or in large aggregations (Barham et al. 1967, Barnes et al. 1976, Billett \& Hansen 1982). Of the 6 orders of holothurians, the Elasipoda are the most common in the deep-sea. Although the taxonomy and zoogeography of this order have been described extensively by Hansen (1975), our knowledge of the reproductive biology of deep-sea holothurians remains rather limited. In general, shallow-water holothurians show a wide variety of reproductive habits (Hyman 1955) but only the commercially important species of shallow-water holothurians have received much attention (Tanaka 1958, Krishnaswamy \& Krishnan 1967, Krishnan 1968, Conand 1981). Elsewhere, especially along the seaboard of North America, studies of a limited number of brooding and indirectly developing species have been undertaken (Pearse 1968, Rutherford 1973, Green 1978, Engstrom 1980).
In accounts of the truly deep-sea species, reproduction has usually been given little more than cursory attention. Mortensen (1927) and Heding $(1935,1942)$ briefly discuss egg size in relation to development within deep-sea holothurians whilst Hansen (1975) devotes a section of his monograph on the Elasipoda to reproduction, although the number of specimens examined is small. More recently, Billett \& Hansen (1982) described the egg size of the elasipod Kolga hyalina as $180 \mu \mathrm{m}$ diameter and predicted lecithotrophic development, whilst for the dendrochirote Ypsilothuria bitentaculata (mistakenly given as $Y$. talismani; see Gage et al. 1985), Tyler \& Gage (1983) described a maximum fecundity of $<50$ eggs individual $^{-1}$ with the eggs growing to a maximum size of $350 \mu \mathrm{m}$. This was thought to suggest lecithotrophic development, with a reduced larval stage for this species.

Laetmogone violacea is considered to be a typically bathyal species with almost a cosmopolitan distribution that may be dependent on ocean currents (Hansen 1975). It has a general depth range of 225 to $1804 \mathrm{~m}$ (Hansen 1975) but in the Rockall Trough and Porcupine Seabight, it is found at depths of 700 to $1500 \mathrm{~m}$. Benthogone rosea appears to have a widespread distribution in the E. Atlantic, S. W. Pacific and W. Indian 

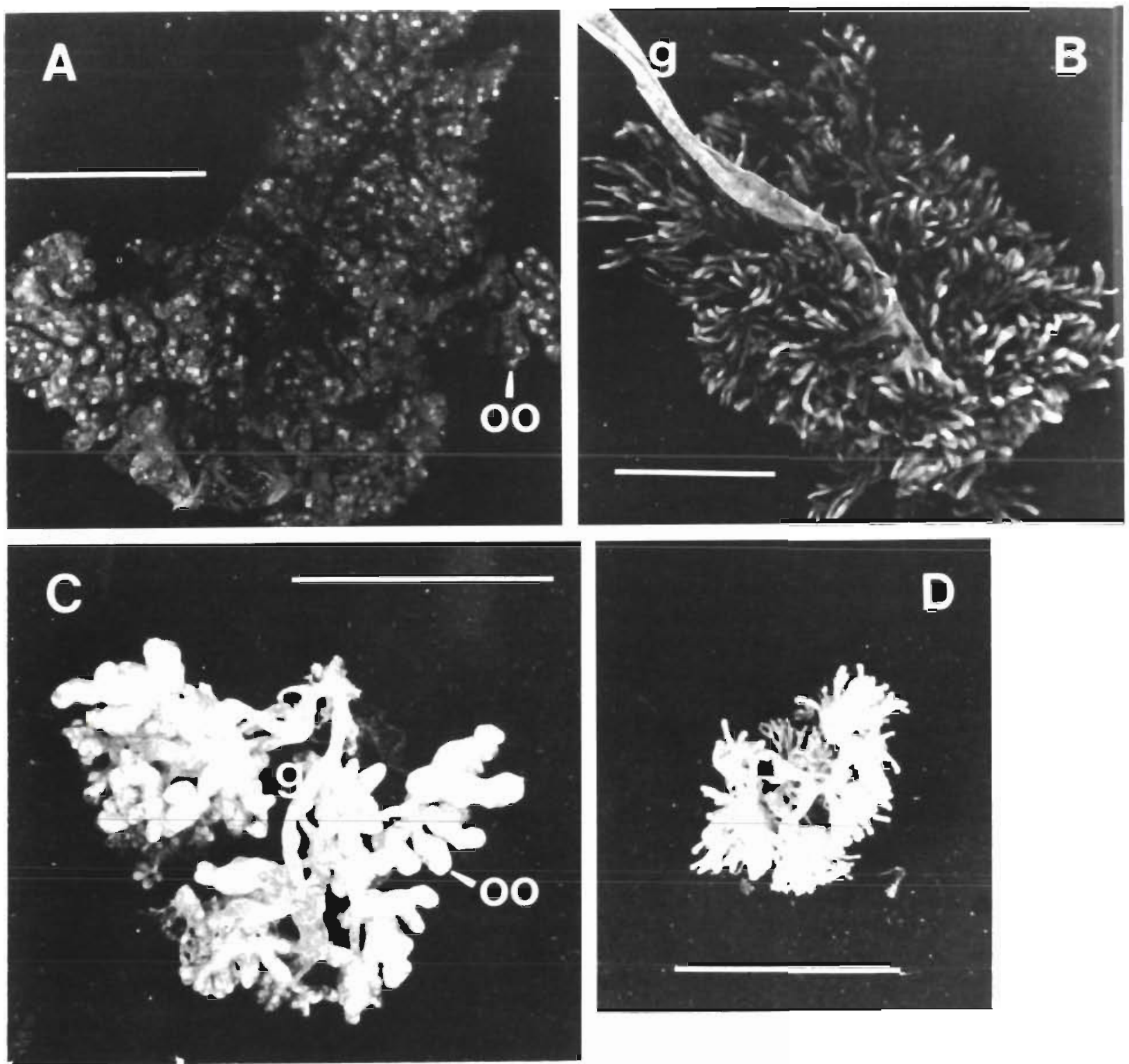

Fig. 1. Gross morphology of gonads. (A) Laetmogone violacea, ovary, (B) testis. (C) Benthogone rosea, ovary, (D) testis. g: gonoduct; oo: oocyte. Bar: $10 \mathrm{~mm}$

develops it is surrounded by follicle cells which are believed to act as nutritive support cells for the developing oocyte. Rarely were oocytes observed to be undergoing phagocytosis.

Histologically the gonoduct consists of the epithelial linings of the ovary wall but these are separated by a very thick connective tissue layer and two layers of muscle.

To determine the oocyte size distribution in each specimen, and to determine any variation between samples, oocyte size-frequency figures have been constructed. Examination of individual specimen oocyte size-frequencies suggests that there is a pool of immature oocytes $<150 \mu \mathrm{m}$ which numerically constitute the vast majority of oocytes present and that some of these develop, undergo vitellogenesis and grow to a maximum size of ca $350 \mu \mathrm{m}$ diameter before being spawned. There is some suggestion that these vitellogenic oocytes develop as a distinct cohort, whilst in other specimens there is a steady production of vitellogenic oocytes.

Within the sample-summated oocyte size-frequency figure (Fig. 3) there is no evidence of any reproductive seasonality although no winter or early spring samples have been collected. These data have been analysed by an $\mathrm{r} \times \mathrm{k}$ contingency table and the null hypothesis that there is no difference between the 9 samples is accepted $\left(\chi^{2}=90.55, \mathrm{df}=96, p=<0.001\right)$. 

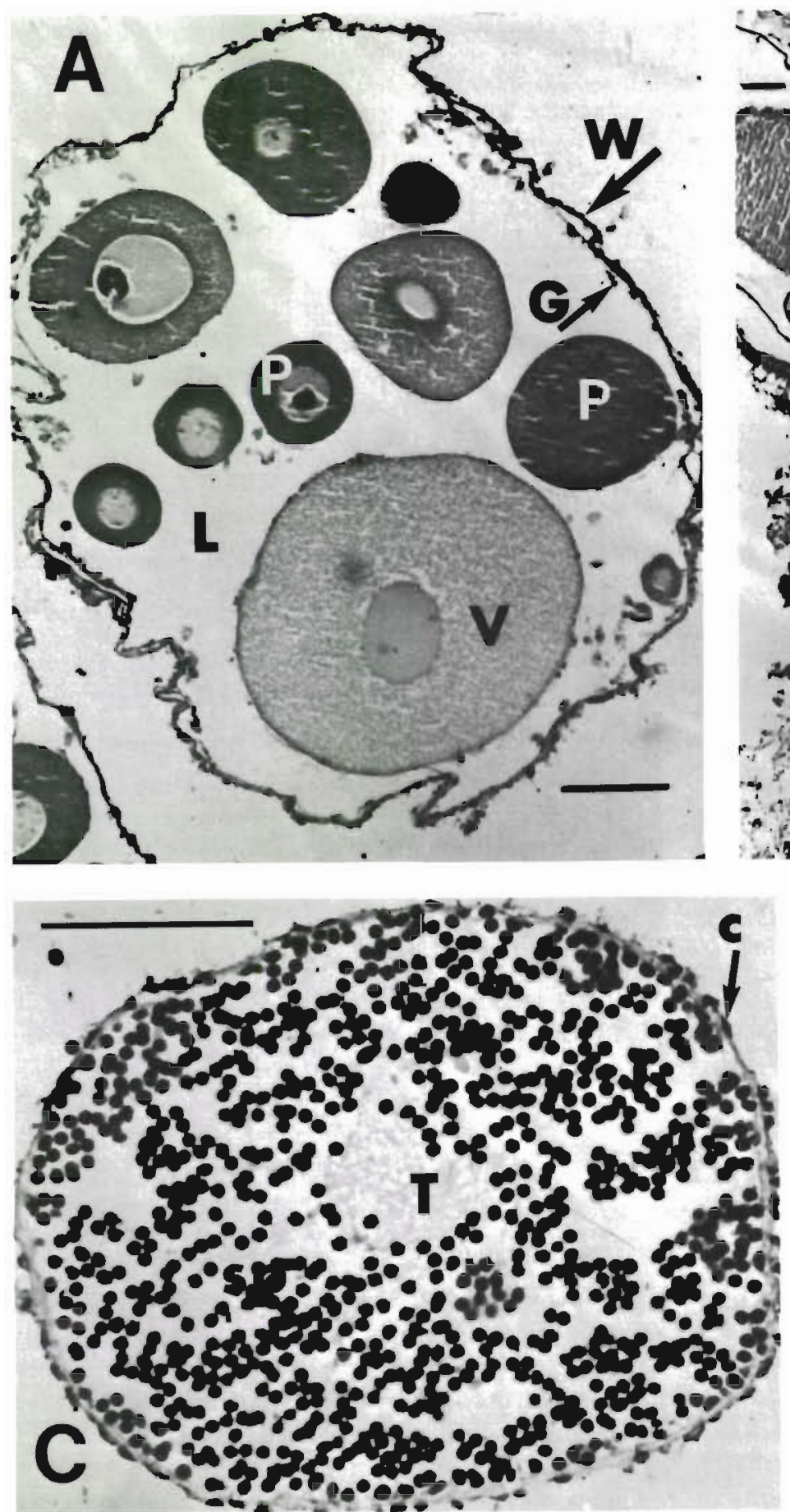
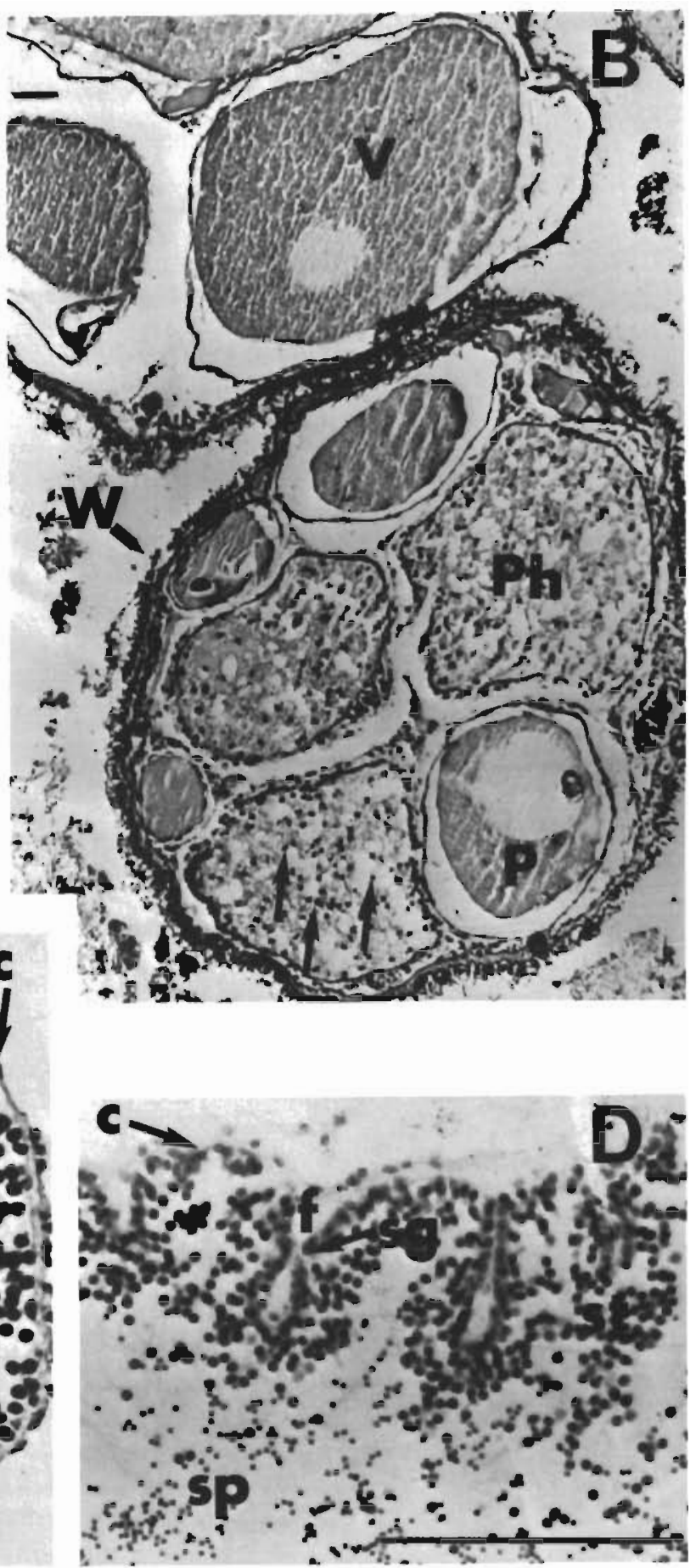

Fig. 2. (A) Laetmogone violacea, oogenesis; (B) Benthogone rosea, oogenesis; (C) B. rosea, spermatogenesis; (D) L. violacea, spermatogenesis. W: gonad wall; P: previtellogenic oocyte ${ }_{i}$ V: vitellogenic oocyte; L: lumen of gonad; G: germinal epithelium; $\mathrm{Ph}$ : phagocytosed oocyte; $\Rightarrow$ : individual phagocytes in $(\mathrm{B})_{i}$ sp: spermatozoa; $\mathrm{T}$ : sperm tails; c: coelomic epithelium; sg: spermatogonia; $f$ fold in germinal epithelium. Horizontal bars: $100 \mu \mathrm{m}$. All haemalum and eosin except (A) (Toluidine blue)

Microscopic and oocyte size-frequency observations of gametogenesis in Benthogone rosea

The wall structure of Benthogone rosea is similar to that of Laetmogone violacea except that there is a much greater cellular presence in $B$. rosed than in $L$. violacea. The original clumps found in $L$. violacea are not as easy to identify in $B$. rosea. However, subcellular previtellogenic oocyte growth appears to follow a similar pattern although oocytes in this stage in 


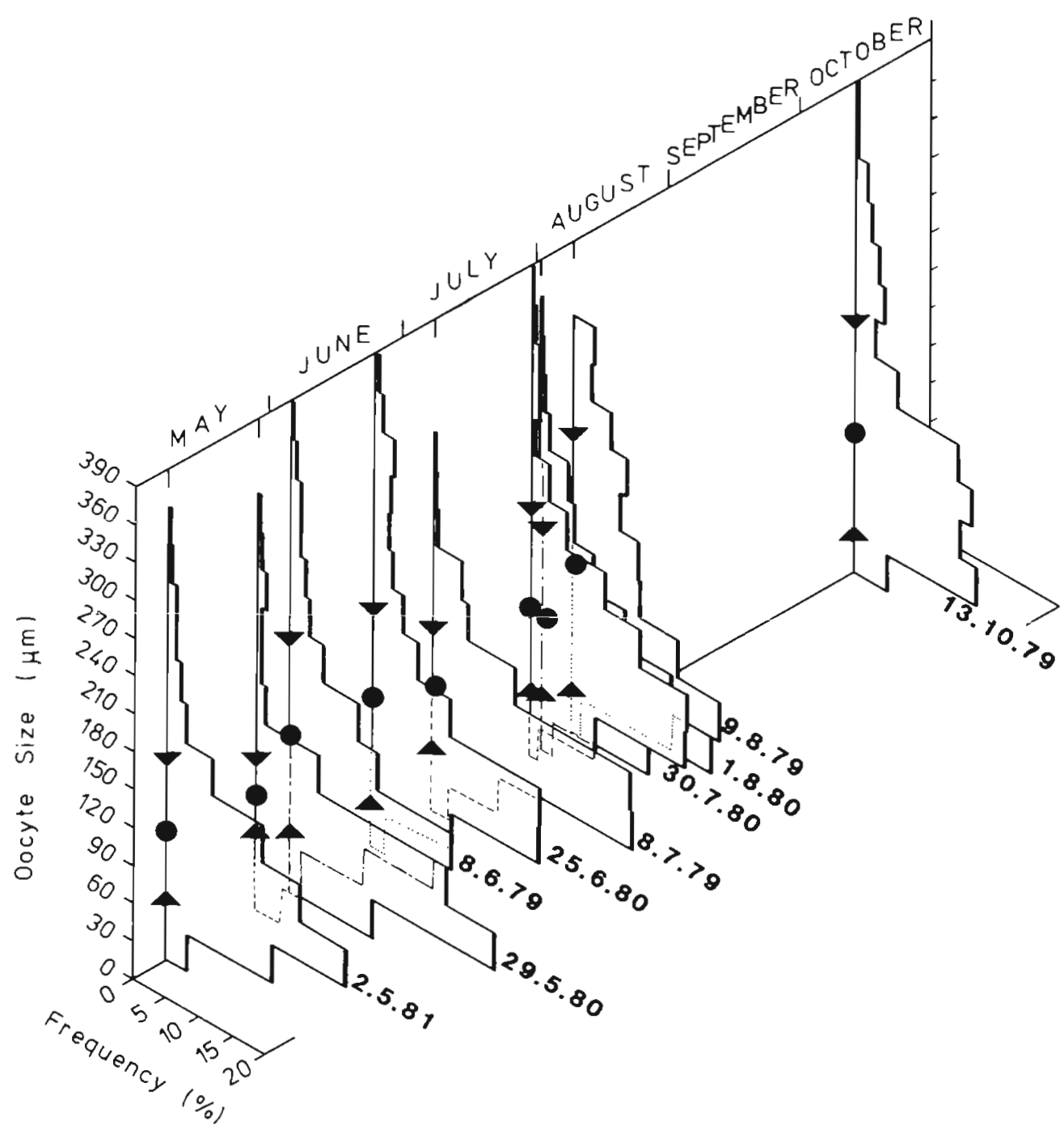

Fig. 3. Laetmogone violacea. Summated sample oocyte size-frequency of all seasonal samples. Samples from different years are plotted on an annual axis; $\bullet$ mean oocyte size; $\Delta \pm 1$ standard deviation

B. rosea are surrounded by numerous follicle cells (Fig. 2B). Vitellogenesis appears to commence at an oocyte diameter of about $300 \mu \mathrm{m}$. At this stage, fine PASpositive granules appear and the oocyte then grows to a maximum size of $750 \mu \mathrm{m}$. There is some evidence from sections through the tips of the gonad tubules that previtellogenic activity is highest at these distal points. In the largest oocytes (ca $700 \mu \mathrm{m}$ ) the cytoplasm contains dense granular PAS-positive material and in some oocytes a 'dent' in the nucleus appears to open to the oocyte surface. The nucleolus is also very eccentric within the nucleus.

Some oocytes, particularly in the range 200 to 300 $\mu \mathrm{m}$ diameter were permeated with follicle cells suggesting some form of phagocytic process. The follicle cells that had supported the early growth of the oocyte now invade the oocyte and result in its complete breakdown (Fig. 2B). The proportion of oocytes $>200$ $\mu \mathrm{m}$ being broken down varied from zero in newly developed specimens to ca $40 \%$ in well developed specimens. This 'nurse cell' pattern has been observed in a number of deep sea asteroids (Tyler et al. 1982a, Pain 1983).

On capture, a large number of Benthogone rosea were found to have eviscerated. In many cases only a few gonadial strands could be found, just enough to determine the sex. In the remaining cases oocyte sizefrequency analyses were attempted, but we believe that partial spawning of many of the specimens had taken place during capture. However, we present oocyte size-frequency counts for 7 intact specimens (Fig. 4). These data suggest there is a 'pool' of previtellogenic oocytes $<250 \mu \mathrm{m}$ diameter and that from this pool a limited number of oocytes undergo vitel- 
logenesis, possibly supported by phagocytosed oocytes, to reach the maximum oocyte size of $750 \mu \mathrm{m}$ at which point they are spawned. The paucity of large oocytes in these figures suggests some release of gametes took place during capture. This pattern is typical of deep-sea asteroids with direct development (Tyler et al. 1983).

\section{Spermatogenesis in Laetmogone violacea and Benthogone rosea}

The germinal epithelium of the testis of Laetmogone shows numerous infoldings (Fig. 2D) that are lined with spermatogonia (ca $70 \mu \mathrm{m}$ diameter). These divide to give a thin layer of spermatocytes which then undergo reduction division to produce spermatids that mature into round-headed spermatozoa $(2.0 \mu \mathrm{m}$ diameter). The testis appeared to be in a continually mature condition ready for spawning on meeting a female.

The germinal epithelium of the testis of Benthogone rosea rarely showed the infolding found in Laetmogone violacea except in some narrow distal tubules.
The gonads usually contained loosely packed spermatozoa (Fig. 2C) with very little evidence of other spermatogonial cells. The heads of these spermatozoa were large (ca 5 to $7 \mu \mathrm{m}$ diameter) and round, whilst the sperm tail extended into the lumen of the testis.

\section{DISCUSSION}

It is of considerable interest that these 2 closely related elasipod holothurians show interspecific variability in their reproductive pattern. Both are widespread species with Laetmogone violacea being found on the upper to mid-continental slope, whilst Benthogone rosea is found on the middle and lower slope. All the specimens we have examined are mature, although at least $50 \%$ of specimens of $B$. rosea had totally eviscerated during capture. Hansen (1975) suggests that $L$. violacea reaches reproductive maturity at $50 \mathrm{~mm}$ length whilst the smallest specimen of $B$. rosea examined (ca $44 \mathrm{~mm}$ ) was already undergoing development.

The pattern of early oogenesis, with oogonia giving

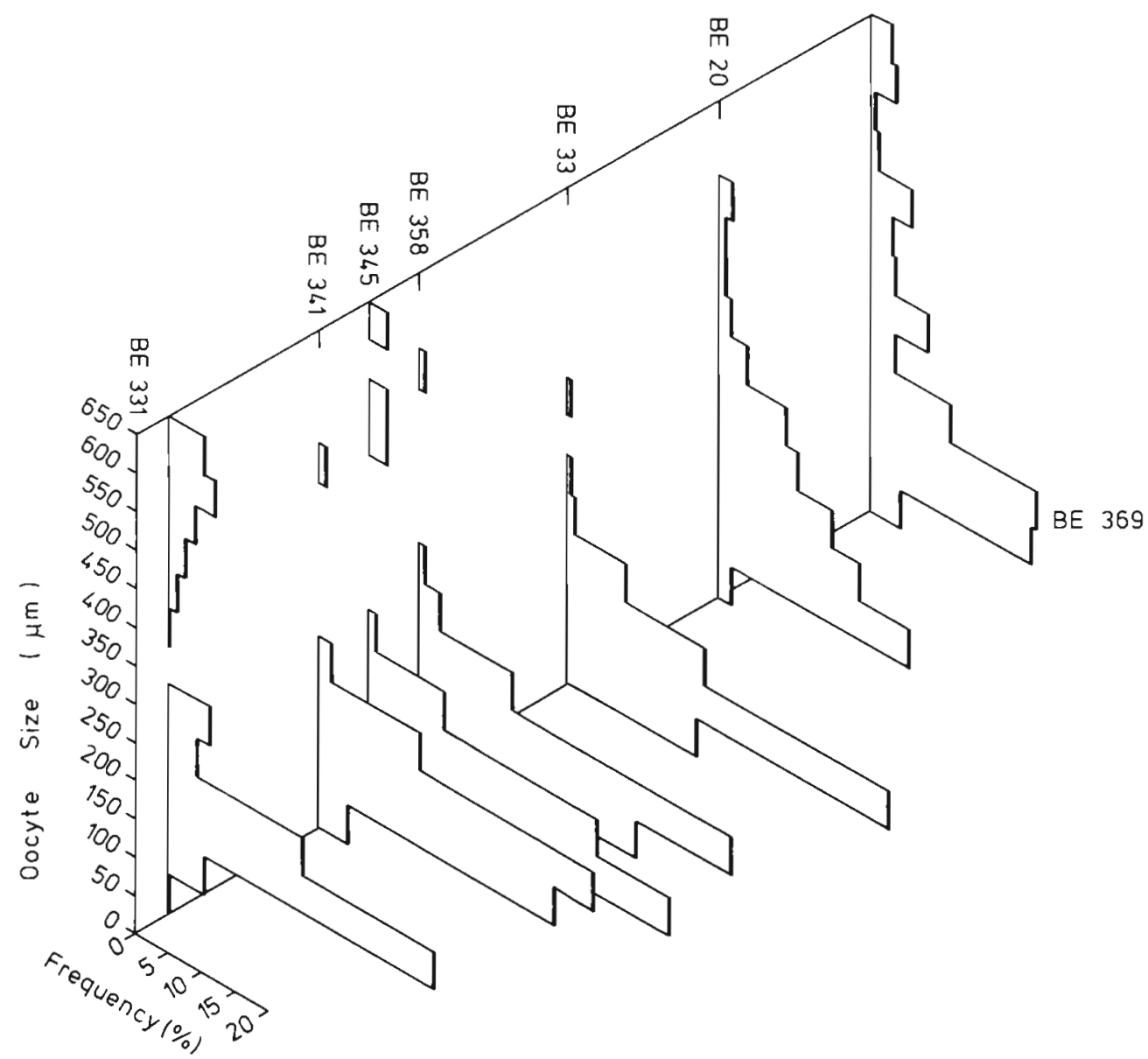

Fig. 4. Benthogone rosea. Oocyte size-frequency values of individuals that had not eviscerated on capture 
rise to previtellogenic oocytes, would appear to be similar in both species. In Laetmogone violacea these oocytes begin yolk production at about $150 \mu \mathrm{m}$ before increasing in size to a maximum of $350 \mu \mathrm{m}$ diameter. However, the oocytes of Benthogone rosea remain previtellogenic until about $300 \mu \mathrm{m}$ diameter before undergoing yolk production to produce eggs in excess of 750 $\mu$ m diameter. In both species the germinal vesicle was intact, even in the largest oocytes, suggesting that reduction division takes place immediately before spawning, or in the water column after spawning. In $L$. violacea nearly all the oocytes were spawned whereas in $B$. rosea a number of oocytes in the size range 200 to $300 \mu \mathrm{m}$ underwent phagocytic breakdown. During egg production follicle cell activity appeared to be much greater in $B$. rosea than in $L$. violacea.

From these data we can make certain inferences. The egg size of Laetmogone violacea is considered an 'intermediate' egg size between the small eggs of planktotrophic developers $(<100 \mu \mathrm{m})$ and the large eggs $(>600 \mu \mathrm{m})$ of direct developers. This intermediate egg size has been found in only 2 other deep-sea echinoderms, both typically slope species, the large epifaunal brittle star Ophiomusium lymani and the small, deposit-feeding dactylochirote Ypsilothuria bitentaculata (Gage \& Tyler 1982, Tyler \& Gage 1983, as $Y$. talismani). By comparison with shallow-water species (Hendler 1979), it is suggested that this size of egg gives rise to an 'abbreviated' larva.

Although no direct evidence is available we may expect these abbreviated larvae to be dispersed throughout the adult population by near-bed current activity.

As with other echinoderm species producing an egg of the intermediate size, spawning is a complete process in Laetmogone violacea. Maximally developed oocytes are rarely found undergoing follicle cell activity, thus negating the need for any recycling processes. In contrast, Benthogone rosea produces the large egg typical of direct development to a juvenile usually considered to occur close to the adult population. It would appear that large eggs are more difficult to maintain in the ovary and if not spawned are phagocytosed by follicle cell activity so that the energy is retained within the adult rather than being lost to the environment. This dichotomy of follicle cell activity between those species producing intermediate and large eggs is a common feature amongst oogenesis in deep sea echinoderms.

From the available data there was no evidence of reproductive synchrony related to any of the seasonal phenomena that have been recently identified from the deep-sea (Deuser \& Ross 1980, Deuser et al. 1981, Dickson et al. 1982, Tyler et al. 1982, Billett et al. 1983).
The reproductive pattern observed in Laetmogone violacea and Benthogone rosea would appear to be more typical of deep sea echinoderms as 30 out of 36 species so far examined appear to reproduce year round.

Within the males the spermatogenic process was not distinctly different between the species. The germinal epithelium of the testes of Laetmogone violacea was in folds which increases the surface area of spermatogenesis. The much larger sperm head (ca $7 \mu \mathrm{m}$ ) of Benthogone rosea, compared to that of $L$. violacea (ca 2 to $3 \mu \mathrm{m}$ ) may be related to the need to penetrate the larger egg of $B$. rosea.

These data pose a number of questions. First, the rate of vitellogenesis and egg production in each species remains unknown; it may take weeks, or years. After feeding we do not know how long storage lasts; nutrients may be stored in the body wall in holothurians or transported directly to the gonads. The lateral or vertical transport of large eggs is not usualiy expected, but an abbreviated larva may be transported up, down or along the slope perhaps for considerable distances.

Acknowledgements. We thank Professor F. T. Banner in whose department the work was carried out; the Master und Crew of R. R. S. 'Challenger' for their assistance at sea. The Scottish Marine Biological Association is Grant-aided by the Natural Environment Research Council. This research was carried out under contract from the Department of the Environment as part of its radioactive waste management research programme. While the results may be used in the formulation of Government policy, at this stage they do not necessarily represent Government policy

\section{LITERATURE CITED}

Aldred, R. G., Thurston, M. H., Rice, A. L., Morley, D. R. (1976). An acoustically monitored opening and closing epibenthic sledge. Deep Sea Res. 23: 167-174

Barham, E. G., Ayer, N. J., Boyce, R. E. (1967). Macrobenthos of the San Diego Trough; photographic census and observations from bathyscaphe Trieste. Deep Sea Res. 14: 773-784

Barnes, A. T., Quetin, L. 8., Childress, J. J., Pawson, D. L., (1976). Deep-sea macroplanktonic sea cucumbers: suspended sediment feeders captured from deep submergence vehicle. Science 194: 1083-1085

Billett, D. S. M., Hansen, B. (1982), Abyssal aggregations of Kolga hyalina D \& $\mathrm{K}$ (Echinodermata: Holothurioidea) in the N. E. Atlantic Ocean: a preliminary report. Deep Sea Res. 29: 799-818

Billett, D. S. M., Lampitt, R. S., Rice, A. L., Mantoura, R. F. C. (1983). Seasonal sedimentation of phytoplankton to the deep-sea benthos. Nature, Lond. 302: 502-522

Conand, C. (1981). Sexual cycle of three commercially important holothurian species (Echinodermata) from the lagoon of New Caledonian. Bull. mar. Sci. 31: 523-543

Deuser, W. G., Ross, E. H. (1980). Seasonal change in the flux of organic carbon to the deep Sargasso Sea. Nature, Lond. 283: $364-365$

Deuser, W. G., Ross, E. H., Anderson, R. F. (1981). Seasonality 
in the supply of sediment to the deep Sargasso Sea and its implications for the rapid transfer of matter to the deep ocean. Deep Sea Res. 28: 495-505

Dickson, R. R., Gould, W. J., Gurbutt, P. A., Killworth, P. D (1982). A seasonal signal in ocean currents at abyssal depths. Nature, Lond. 295: 193-198

Engstrom, N. A. (1980). Reproductive cycles of Holothuria (Halodeima) floridana, $H$. (H.) mexicana and their hybrids (Echinodermata: Holothuroidea) in southern Florida, USA. Int. J. Invert. Rep. 2: 237-244

Filatova, Z. A. (1969). The quantitative distribution of the deep-sea bottom fauna. In: Kort, V. G. (ed.) The Pacific Ocean, Vol. 7, Biology of the Pacific Ocean, Book 2, The deep bottom fauna. Nauka Moskow, p. 202-216

Gage, J. D., Tyler, P. A. (1981). Growth and reproduction in the deep-sea brittlestar Ophiomusium lymani Wyville Thomson. Oceanologica Acta 5: 73-83

Gage, J. D., Billett, D. S. M., Jensen, M., Tyler, P. A. (1985). Echinoderms of the Rockall Trough. II. Echinoidea and Holothurioidea. Bull. Br. Mus. nat. Hist. (in press)

Grant, A., Tyler, P. A. (1983). The analysis of data in studies of invertebrate reproduction. I. Introduction and statistical analysis of gonad indices and maturity indices. Int. J. Invert. Rep. 6: 259-269

Green, J. D. (1978). The annual reproductive cycle of an apodous holothurian Leptosynapta tenuis: a biomodal breeding season. Biol. Bull. mar, biol. Lab., Woods Hole 154: $68-78$

Hansen, B. (1975). Systematics and biology of the deep-sea holothurians. I. Elasipoda. Galathea Rep. 13: 1-262

Heding, S, G. (1935). Holothurioidea. Part. I. Apoda-Molpadioidea-Gephyrothurioidea. Danish-Ingolf Expedition 4 (9): 1-84

Heding, S. G. (1942). Holothurioidea. Part. II. AspidochirotaElasipoda-Dendrochirota. Danish-Ingolf Expedition 4 (13): $1-39$

Heezen, B. C., Hollister, C. D. (1971). The face of the deep. Oxford University Press, New York

Hendler, G. (1979). Reproductive periodicity of Ophiuroids (Echinodermata: Ophiuroidea) on the Atlantic and Pacific coasts of Panama. In: Stancyk, S. E. (ed.) Reproductive ecology of marine invertebrates. Univ. of S. Carolina Press, Columbia, p. 145-156

Hessler, R. R., Sanders, H. L. (1967). Faunal diversity in the deep sea. Deep Sea Res. 14: 65-78

Hyman, L. (1955). The invertebrates. IV. Echinodermata. McGraw Hill Book Co., New York

Khripounoff, A., Desbruyères, D., Chardy, P. (1980). Les peu- plements benthiques de la faille Vema: données quantitatives et bilan d'énergie en milieu abyssal. Oceanologica Acta 3: 187-198

Krishnan, S. (1968). Histochemical studies on reproductive and nutritional cycles of the holothurian Holothuria scabra. Mar. Biol, 2: 54-65

Krishnaswamy, S., Krishnan, S. (1967). A report on the reproductive cycle of the holothurian Holothuria scabra. Curr. Sci. 36: 155-156

Menzies, R. J., George, R. Y., Rowe, G. T. (1973). Abyssal environment and ecology of the world oceans. Wiley \& Sons, London

Mortensen, T. (1927). Handbook of the echinoderms of the British Isles. Oxford University Press, London

Pain S. L. (1983). Aspects of gametogenesis in deep-sea Asteroidea from the Rockall Trough, N. E. Atlantic. Ph. D. thesis, University of Wales

Pawson, D. L. (1966). Ecology of Holothurians. In: Boolootian, R. A. (ed.) Physiology of Echinodermata, Interscience Pub., New York, p. 63-71

Pearse, J. S. (1968). Patterns of reproductive periodicities in four species of Indo-Pacific Echinoderms. Proc. Indian Acad. Sci. (B) $67: 247-279$

Rutherford, J. C. (1973). Reproduction, growth and mortality of the holothurian Cucumaria pseudocurata. Mar. Biol. 22: $167-176$

Sibuet, M. Lawrence, J. M. (1981). Organic content and biomass of abyssal holothuroids (Echinodermata) from the Bay of Biscay. Mar. Biol. 65: 143-147

Tanaka, Y. (1958). Seasonal changes in the gonad of Stichopus japonicus. Bull. Fac. Fish. Hokkaido Univ. 9: 29-36

Tyler, P. A., Grant, A., Pain, S. L., Gage, J. D. (1982a). Is annual reproduction in deep-sea echinoderms a response to variability in their environment? Nature, Lond. 300: $747-750$

Tyler, P. A., Pain, S. L., Gage, J. D. (1982b). The reproductive biology of the deep-sea asteroid Bathybiaster vexillifer. J. mar. biol. Ass. U. K. 62: 57-69

Tyler, P. A., Gage, J. D. (1983). The reproductive biology of Ypsilothuria talismani (Holothuroidea: Dendrochirata) from the N. E. Atlantic. J. mar. biol. Ass. U. K. 63: 609-616

Tyler, P. A., Pain, S. L., Gage, J. D. (1983). Gametogenic cycles in deep-sea phanerozoan asteroids from the N. E. Atlantic. In: Lawrence, J. M. (ed.) International Echinoderm Conferences, Tampa Bay. A. A. Balkema, Rotterdam, p. 431-434 


\title{
Niche separation within the mobile predator guild on marine shallow soft bottoms
}

\author{
Sverker Evans \& Bo Tallmark \\ Department of Zoology, Uppsala University, Box 561, S-751 22 Uppsala, Sweden
}

\begin{abstract}
Segregation of coexisting predatory fish and shrimp species on marine shallow soft bottoms was studied in the Gullmar Fjord (Sweden). Here, the gobiids Pomatoschistus minutus (Pallas) and P. microps (Kroyer) and the brown shrimp Crangon crangon L. are the most abundant epibenthic species close inshore. A temporary reduction in number of one of the species was balanced by an increased recruitment of other species in the guild, so that the overall density of epibenthic predators was kept at approximately the same level. Experimental validation of field results showed that segregation maintained by interspecific territoriality is an important mechanism regulating guild structure. We argue that competitive relations undoubtedly are of importance in maintaining structure of the epibenthic communities in Gullmar Fjord, but of minor importance for overall density of the guild.
\end{abstract}

\section{INTRODUCTION}

In coexisting species, the habitat niche generally is of greater importance than either food and time dimensions for the segregation of guild members (Schoener 1974). On uncovered or sparsely vegetated marine, shallow soft bottoms, total density and diversity of small-sized fish and shrimp species are low. Presumably this is so because predators are effective in this habitat and therefore reduce prey populations. The vegetated habitat, on the other hand, may provide sufficient structural complexity to reduce the potency of predation, and the abundance and diversity of the epibenthic community increases. Access to shelter will protect coexisting animals, and competition is likely to be of greater importance. On shallow sandy bottoms the number of niches is low and the species occupying such areas are presupposed to exploit a common pool of resources and occupy relatively broad niches with wide overlaps.

The abundant epibenthic predator guild close inshore on shallow soft bottoms in Gullmar Fjord (Swedish west coast) is dominated by the gobiid fishes Pomatoschistus minutus (Pallas) and $P$. microps (Krøyer), and the brown shrimp Crangon crangon $\mathrm{L}$. During summer these species gather in shallow water where they coexist in much larger numbers than in deeper water (Evans \& Tallmark 1984). All 3 species behave as generalists with respect to food, and show only a small temporal segregation in peak abundances (Evans \& Tallmark 1979, 1984, Evans 1983). Due to the rich food supply provided by the benthic community, including small conspecifics, competition for food is not discernible, despite a wide overlap in dietary habits (Evans 1983, 1984). An almost continuous recruitment of new cohorts of fishes and shrimps to shallow water during summer will probably swamp the impact of potential predators. Thus, other factors must regulate the structure of the epibenthic community in the shallow soft bottom environment.

In this paper we evaluate the importance of a complex habitat for the structure of the epibenthic community in 3 shallow bays which display different physical features. We also provide experimental evidence of territoriality as an important agent for epibenthic guild structure on sandy bottoms. This leads to a discussion of the role of competitive relations and predation for the epibenthic community structure in different habitats.

\section{AREA DESCRIPTION}

The study area comprised 3 sandy bays, less than $2 \mathrm{~km}$ apart, at the mouth of Gullmar Fjord, Swedish west coast $\left(58^{\circ} 15^{\circ} \mathrm{N}, 11^{\circ} 28^{\prime} \mathrm{E}\right)$. In this area, there are virtually no tides $( \pm 5 \mathrm{~cm}$; spring tide $\pm 15 \mathrm{~cm})$. The 
Table 1. General description of investigation areas. HWL = high water level

\begin{tabular}{lccc|}
\hline \multicolumn{1}{c}{ Parameter } & Kvarnbukten Bay & Bökevik Bay & Kilviken Bay \\
\hline Area $\left(\mathrm{m}^{2}\right)$ & 36,000 & 20,500 & 6,500 \\
Depth $(\mathrm{m})$ & HWL -1 & HWL -1 & HWL -0.5 \\
Exposedness & Moderately exposed & Moderately sheltered & Very sheltered \\
Grain size $(\%)$ & & & 1 \\
Pebble, granule $>2 \mathrm{~mm}$ & 6 & 7 & 9 \\
Very coarse to medium sand $0.25-2 \mathrm{~mm}$ & 9 & 21 & 76 \\
Fine to very fine sand 0.06-0.25 mm & 82 & 66 & 14 \\
Silt, clay <0.06 mm & 3 & 6 & $3.3 \pm 2.6$ \\
Org. matter (\% d. wt.) & $0.4 \pm 0.04$ & $0.7 \pm 0.1$ & Ruppia spp. \\
Vegetation & - & Zostera marina & 40 \\
No. of samples & 124 & 50 & 40 \\
\hline
\end{tabular}

physical features of the 3 bays are summarized in Table 1. As a result of different degrees of exposure, the amounts of silt and vegetation in the bays vary considerably.

\section{MATERIAL AND METHODS}

Sampling and analysis. A sampling programme was performed in the 3 adjacent bays from 1978 to 1980 using the drop-net technique (Evans \& Tallmark 1979, 1984). The size structure and species composition of the epibenthic guild in shallow water ( $\leqslant 1 \mathrm{~m}$ depth) were measured at monthly intervals. In most cases, 6 samples each of $10 \mathrm{~m}^{2}$ bottom area were collected in Kvarnbukten Bay, whereas the numbers of samples in the smaller Bökevik Bay and Kilviken Bay were 4 and 2 , respectively.

Food niche overlap. The degree of similarity in food choice between the closely related sand goby and common goby from Kilviken Bay and Kvarnbukten Bay, which contained different sets of dominant food objects, was investigated in October when both species were most abundant. About 15 individuals of each fish species with sizes between 30 and $45 \mathrm{~mm}$ were collected from each of the two sites and anaesthetized. The different food items in their stomachs were identified and counted. The total number of each prey object was summed and was expressed as a percentage of the total number of individuals of all food categories. Thus, a standard food composition was obtained for each of the 2 gobiids. The food niche overlap $\propto$ was calculated according to McArthur \& Levins (1967).

Growth. The growth of the juvenile common goby and sand goby were recorded from size frequency distributions obtained at monthly intervals.

Interference competition test. The importance of territoriality affecting the distribution of 2 of the coexisting predators on sandy bottoms, viz. brown shrimp and common goby, was investigated in the laboratory.
Aquaria of $20 \times 40 \mathrm{~cm}$ bottom area with sand as substrate were divided into 2 halves by means of a net in which a hole was punched close to the bottom. Representatives of the 2 species were introduced on each side of the net in different numerical combinations. The number of individuals was chosen so as not to exceed maximum field abundance. Mussel flesh was supplied as food in the compartment containing gobies. The hole in the net was provided with a short funnel, protruding into the goby compartment. This allowed the shrimp to migrate into the goby compartment but obstructed the migration of both species in the opposite direction. The movements of both shrimp and gobies between the 2 interconnected compartments was recorded at $6 \mathrm{~h}$ intervals. Subsequently the animals were transferred back to their original compartments and the test was repeated. Each day the test animals were replaced with newly caught ones. Aquaria with identical combinations of the 2 species but without food supply served as controls. Statistical comparisons of the distribution were made using Mann Whitney U-test.

\section{RESULTS}

\section{Species abundance and temporal distribution}

In total, 35 species of larger invertebrates and fishes were collected. Of these, 16 fishes were recorded only occasionally. Among the abundant species, the following were common on bare sand: juvenile plaice Pleuronectes platessa, sand eel Ammodytes spp., sand goby Pomatoschistus minutus, and painted goby Pomatoschistus pictus. In silty and partly vegetated habitats other species were dominant: juvenile flounder Platichtys flesus, juvenile eel Anguilla anguilla, common goby Pomatoschistus microps, black goby Gobius niger, two-spotted goby Gobiusculus flavescens, three-spined stickleback Gasterosteus aculeatus and broad-nosed pipefish Siphonostoma typhle. Sea- 

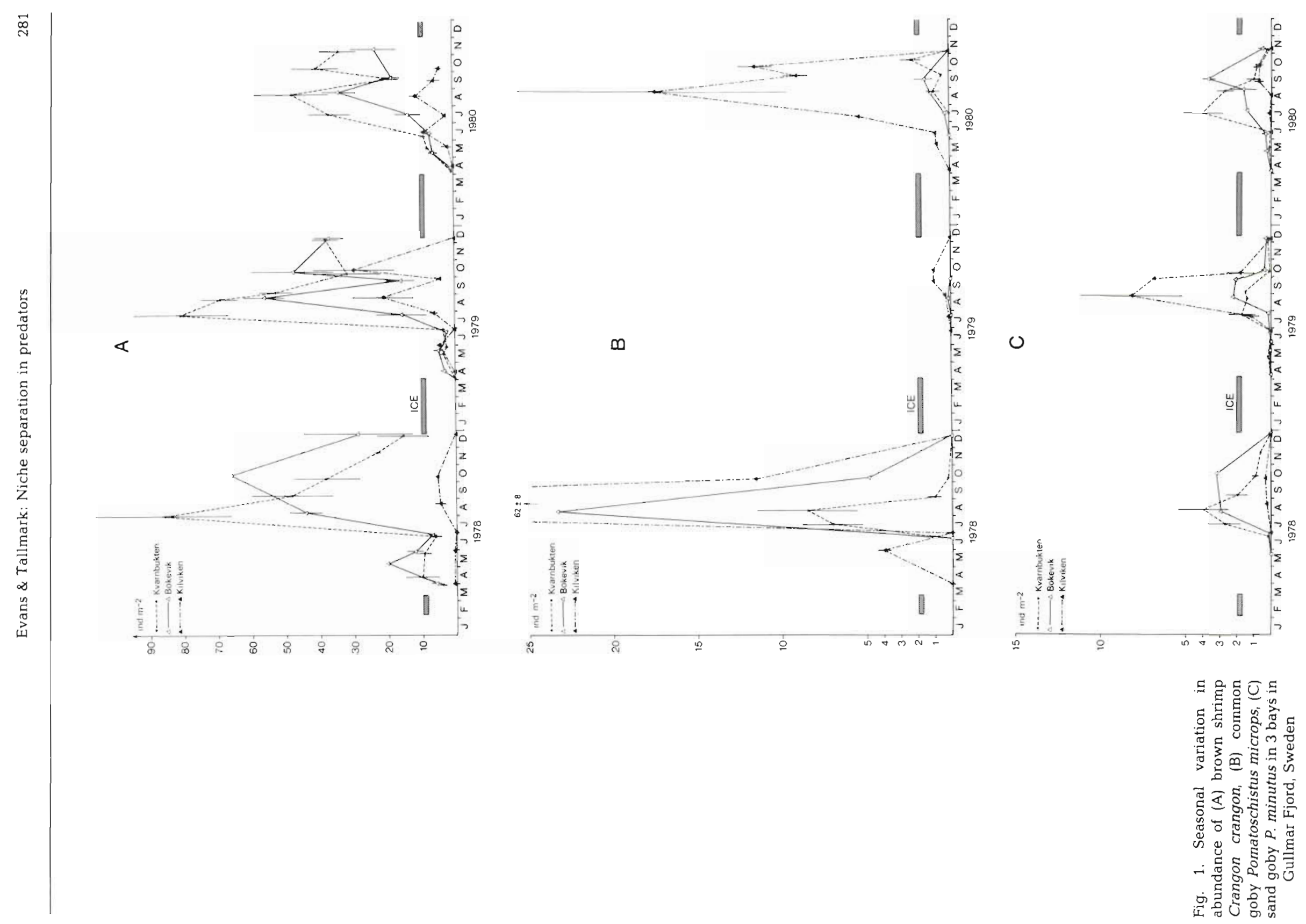
sonal variations in abundance of the numerically dominant epibenthic species in the 3 bays are illustrated in Fig. 1. Both abundance and species composition of the dominant species varied strongly between the years in all 3 bays and were generally larger than differences between the bays. A peak value of about $2.5 \mathrm{~g} \mathrm{~m}^{-2}$ dry weight was recorded in August to October in all 3 yr. The brown shrimp contributed $>80 \%$ of the total biomass in Kvarnbukten Bay but only 10 to $15 \%$ in the other 2 bays. The recruitment of the different species took place synchronously in all 3 bays. The shrimp was more abundant in the unvegetated habitat with a substratum of low organic content. In all 3 yr, an abundance order of shrimp was found: Kvarnbukten>Bökevik>Kilviken. Size distribution of the shrimp consistently differed between the bays throughout the investigation. In Kvarnbukten Bay a higher percentage of juveniles and a lower percentage of very large individuals were recorded, compared to the other 2 bays.

The sand goby was equally abundant in Kvarnbukten Bay and Bökevik Bay (Fig. 1). In Kilviken Bay, the density of the sand goby was considerably lower. In Bökevik and Kilviken Bay, which both support a patchy vegetation, the abundance of the common goby exceeded that in the more uniform Kvarnbukten Bay. This species was dominant in Kilviken Bay in 1978 and 1980. However, in 1979 the recruitment of common gobies to Kilviken Bay was reduced by a factor of more than 20. At the same time, the abundance of sand gobies increased by a factor of 10 at this site, compared to 1978 and 1980 , while the number of shrimp increased 3fold. The absence of common gobies caused a reduction in total abundance of 60 to $90 \%$ in Kilviken Bay, compared to 10 to $20 \%$ in Kvarnbukten and Bökevik Bay.
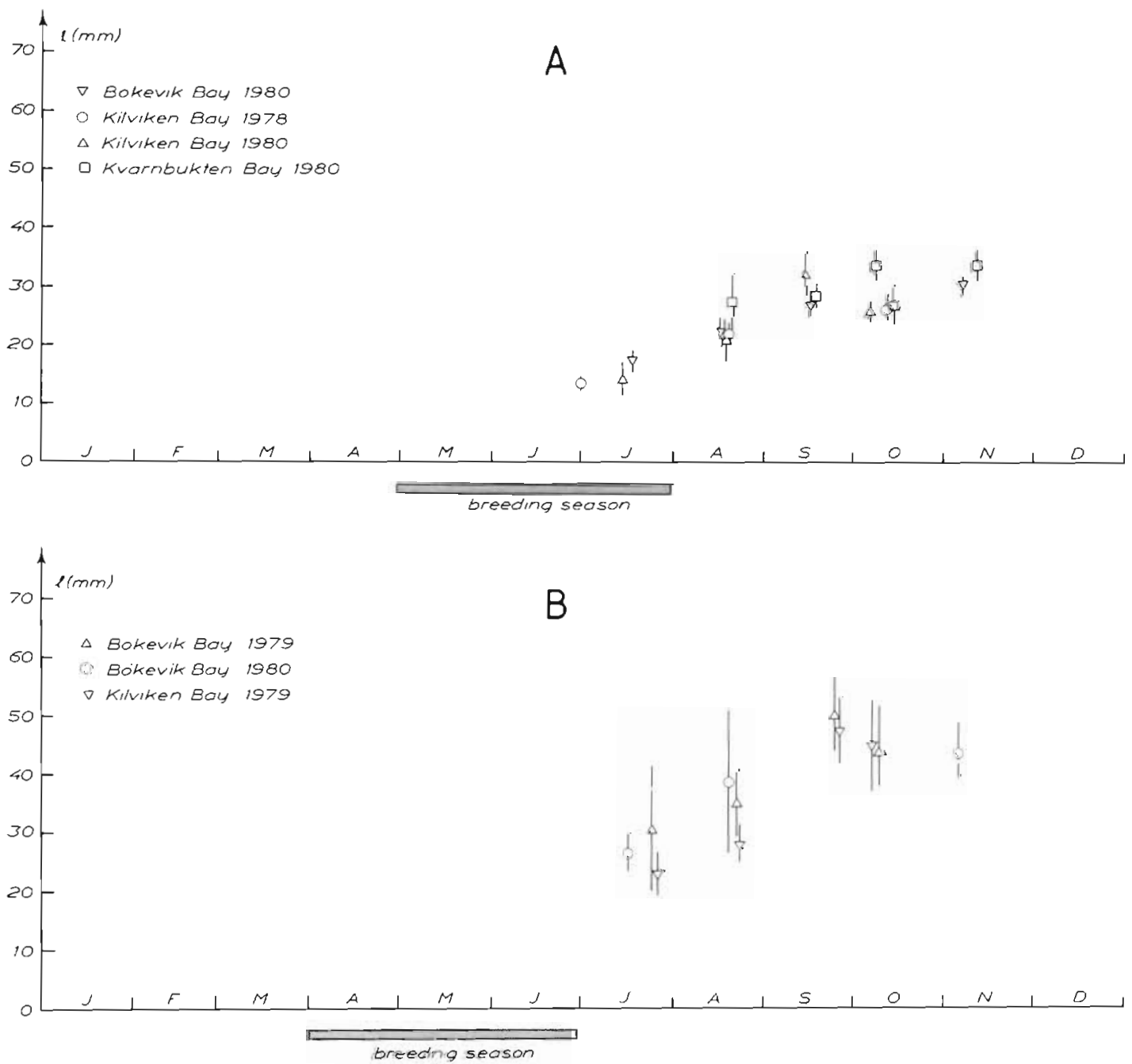

Fig. 2. Growth of 0-group common goby Pomatoschistus microps (A) and sand goby P. minutus (B) in 3 bays in Gullmar Fjord. Mean size $\pm S D$, pooled at monthly intervals 


\section{Growth}

Growth rates of juvenile sand gobies and juvenile common gobies were assessed from size frequency distributions in the different bays (Fig. 2). Once the 0 group appeared, the size frequency distribution of the entire population became bimodal. However, the growth of both species was rapid and about 1 mo after the first appearance of young specimens, the cohort was mixed with older individuals so the different year classes became difficult to recognize. Because of the extended breeding season, changes in mean size of the 0 -group with time was influenced by the successive influx of new juveniles to the population. The actual growth rate was thus likely to be higher than suggested by the mean size determinations. However, the growth rate of the common goby was similar in Danish waters (Muus 1967), and also agreed with that reported from the English Channel (Fouda \& Miller 1981). In the sand goby, monthly growth was between 5 and $10 \mathrm{~mm}$ from July to September, which was somewhat lower than estimated by Swedmark (1957). In Kvarnbukten Bay the growth rates of both gobiids were lower than those found in Kilviken Bay, with the growth rates from Bökevik Bay as an internediate.

\section{Food}

Stomach contents and food-niche overlaps of sand goby and common goby from the 2 sites are presented in Table 2. In Kilviken Bay, chironomids (Chironomus spp.) and the amphipod Corophium volutator made up the bulk of the food of both fish species. In Kvarnbukten Bay, harpacticoid copoepods, which also move actively upon the sandy surface, were totally dominant by number in the stomachs of both fish species. Consequently, food-niche overlaps for the gobiids were close to unity in both habitats.

\section{Interference competition test}

Results of interference competition experiments are presented in Table 3. Experiments run over $24 \mathrm{~h}$ periods showed that the distribution of animals remained fairly stable after 4 to $6 \mathrm{~h}$. When food was supplied to the sand gobies, the number of shrimp penetrating into the goby compartment decreased significantly as the number of gobies increased $(p<0.001$ for all numerical combinations of gobies, Mann Whitney $U$ test). On the other hand, when no food was offered to the gobies, the number of intruding shrimp was positively correlated to the number of gobies present. This is explained by the higher activity of the gobies caused by crowding and food shortage, and this disturbed the shrimp. Similarly, when the shrimp initially had access to the food they prevented the gobies intruding into the food compartment. Thus, the presence of 1 guild member significantly affected the distribution of the other, the number of animals intruding being negatively correlated to the number of animals already present. This implies that there is an upper limit of crowding, regulated by means of aggressive behaviour.

\section{DISCUSSION}

In Gullmar Fjord, the shrimp and 2 gobiid species are adapted to slightly different habitats. The common goby Pomatoschistus microps was found in the innermost parts of the littoral while the sand goby Pomatoschistus minutus was uniformly distributed from high water level (HWL) to $10 \mathrm{~m}$ depth (Evans \& Tallmark 1984). This agrees with observations from the Irish Sea made by Jones \& Miller (1966). They found that the nests of the common goby almost were entirely confined to very shallow shore pools. The eggs of the sand goby, on the other hand, occurred both close inshore and in deeper water (Fonds 1973, Hesthagen 1977 ,

Table 2. Percentage standard composition of stomach contents of sand goby Pomatoschistus minutus and common goby $P$. microps in Kilviken Bay (mud) and Kvarnbukten Bay (sand). $\alpha_{\mathrm{ij}}$ denotes food-niche overlap of sand goby on common goby, and $\alpha_{\mathrm{ji}}$ overlap of common goby on sand goby

\begin{tabular}{|c|c|c|c|c|}
\hline \multirow[b]{2}{*}{ Prey object } & \multicolumn{2}{|c|}{ Kilviken Bay } & \multicolumn{2}{|c|}{ Kvarnbukten Bay } \\
\hline & Sand goby & Common goby & Sand goby & Common goby \\
\hline Meiofauna & 3 & 0 & 3 & 7 \\
\hline Copepods & 0 & 3 & 85 & 90 \\
\hline Polychaetes & 4 & 1 & 1 & $<1$ \\
\hline Chironomids & 53 & 58 & 0 & 0 \\
\hline Corophium volutator & 38 & 37 & 9 & 3 \\
\hline Others & 3 & 1 & 2 & 0 \\
\hline No. of stomachs & 15 & 18 & 15 & 15 \\
\hline No. of prey & 119 & 95 & 181 & 528 \\
\hline Food-niche overlap & $\alpha_{i j}=1.0$ & $\alpha_{\mathrm{j} 1}=0.95$ & $\alpha_{1 \mathrm{j}}=1.0$ & $\alpha_{\mathrm{ji}}=0.94$ \\
\hline
\end{tabular}


Table 3. Frequency distribution of number of shrimp and gobies migrating into the opposite compartment. Number of gobies 0,5 and 10; number of shrimp 5

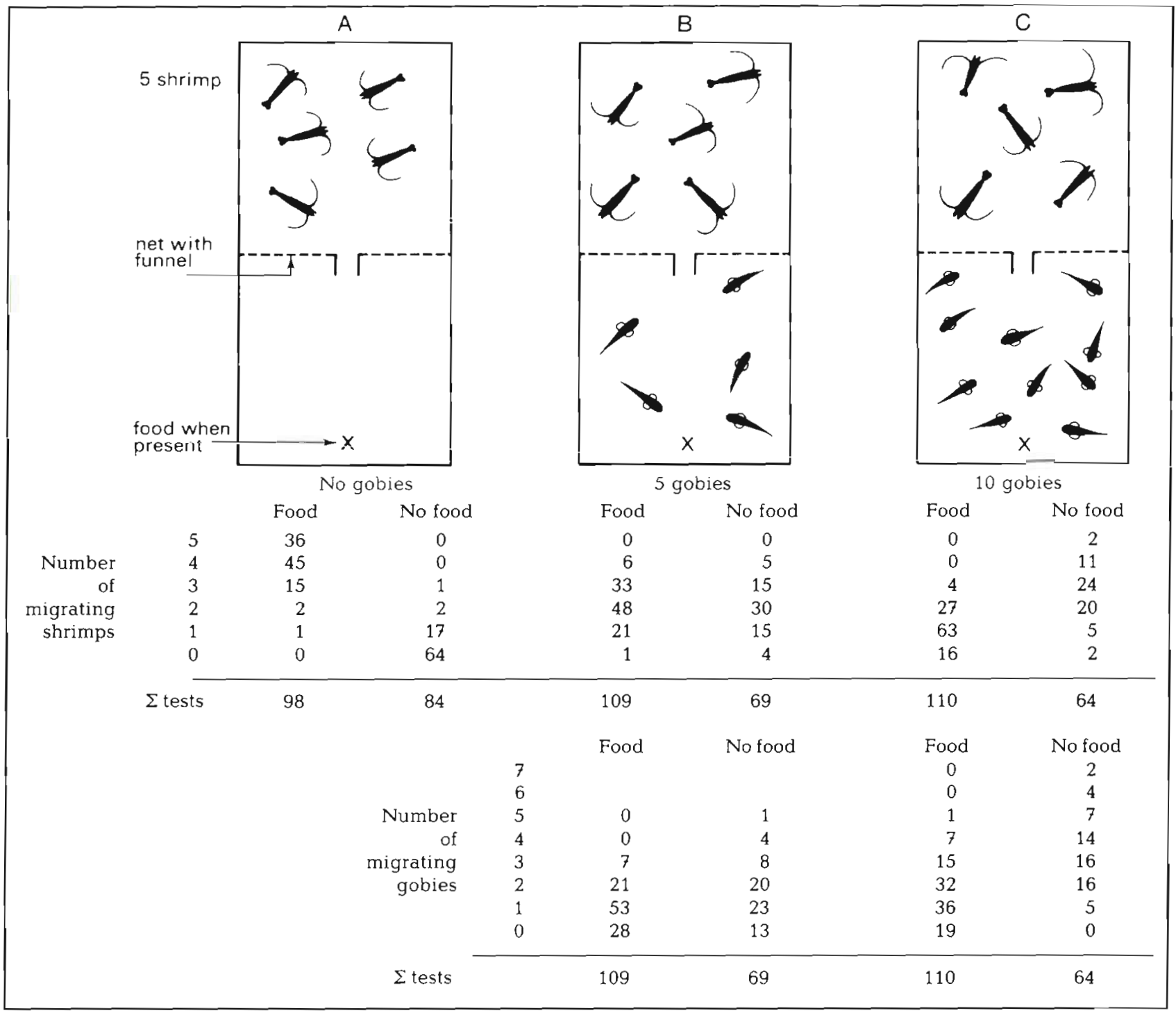

Evans \& Tallmark 1979). According to experimental findings by Fonds \& van Buurt (1974), temperature and salinity boundaries for the development of gobiid eggs will influence gobiid distribution. Eggs of the common goby survived within a narrow temperature range (15 to $20^{\circ} \mathrm{C}$ ), compared to the eggs of the sand goby (10 to $20^{\circ} \mathrm{C}$ ). Furthermore, eggs of the common goby survived well in a wider salinity range (5 to $35 \%$ ), than those of the sand goby (15 to $35 \%$ ). In Kvarnbukten Bay the sand goby bred 1 mo earlier than the common goby (Evans \& Tallmark 1984), which also supports the results of Fonds \& van Buurt (1974). In Gullmar Fjord a slight temporal and spatial segregation of the 2 gobiids may thus occur which should reduce competition for suitable nestsites.

The range of the sand goby population from the shore line down to at least $10 \mathrm{~m}$ depth will allow a considerable population size in shallow water, and lead to the littoral becoming occupied each year. This is in contrast to the common goby which breeds only in shallow water and thus is much more susceptible to physical disturbances than are the other 2 species. In Kilviken Bay, the common goby normally contributed $50 \%$ to the total abundance of the epibenthic guild. In 1979, a failure of this species to appear coincided with a heavy invasion of sand gobies to this habitat (Fig. 1). The brown shrimp too, increased in abundance in Kilviken Bay that year, and it is likely that these events are related. In Kvarnbukten and Kilviken Bay, the lacking recruitment of the common goby did not affect the abundance of the other 2 species. However, the common goby was normally relatively rare in the 
unvegetated habitat and did not contribute significantly to the total abundance. On the other hand, the common goby seemed to have a great impact on the dispersion of the sand goby and brown shrimp populations in the vegetated habitat.

The abundance of fish in the muddy and vegetated habitats, which provide prey refuges, was always higher than on clean sand. In the unvegetated habitat, refuges are lacking and predation keeps the competing species at relatively low densities so that competitive exclusion does not occur. This is in agreement with Connell (1975), who argued that predation is of primary importance for community structure unless reduced by other factors. Therefore, interference competition for space rather than for food resources should be important among motile animals in seagrass meadows.

The structure of the shallow-water community is in part regulated by the environment, which is characterized by large fluctuations in physical variables. However, for consumer populations, the dependence upon other organisms for food probably is more important as regulator than the physical environment, which can be avoided when unfavourable. The presence of abundant opportunistic epibenthic omnivores may result in a predator-regulated community. However, epibenthic predators do not crop infauna to an extent sufficient to reduce infaunal abundance or species composition (Berge \& Hesthagen 1981, Evans 1983, 1984, Quammen 1984). On uncovered or sparsely vegetated sandy bottoms such as Kvarnbukten Bay, total density and diversity of the epibenthic community are low. This presumably is because predators are more effective in this habitat and therefore reduce the populations, and this process reduces the impact of competition. An exceptional case is the brown shrimp which subsists in large numbers on open bottoms. The impact

Table 4. Relative differences in life history strategies of sand goby, common goby and brown shrimp, and their consequences for population dynamics

\begin{tabular}{|c|c|c|c|}
\hline & $\begin{array}{l}\text { Sand } \\
\text { goby }\end{array}$ & $\begin{array}{l}\text { Common } \\
\text { goby }\end{array}$ & $\begin{array}{l}\text { Brown } \\
\text { shrimp }\end{array}$ \\
\hline Life span $(y)$ & $2-(3)$ & $1-(2)$ & $2-3$ \\
\hline Iteroparity & yes? & no? & yes \\
\hline $\begin{array}{l}\text { Spawning grounds } \\
\text { (depth m) }\end{array}$ & $0->10$ & $0-1$ & $>10$ \\
\hline $\begin{array}{l}\text { Susceptibility to } \\
\text { physical disturbances }\end{array}$ & less & more & less \\
\hline Spawning period & Mar-Jul & Apr-Aug & $\begin{array}{c}\text { Apr } \\
\text { Jul-Aug }\end{array}$ \\
\hline Population dynamics & $\begin{array}{l}\text { low } \\
\text { stable }\end{array}$ & $\begin{array}{l}\text { high, } \\
\text { fluct. }\end{array}$ & $\begin{array}{l}\text { high, } \\
\text { stable }\end{array}$ \\
\hline
\end{tabular}

of predators, however, may be swamped out as a result of large settling peaks within restricted areas. In vegetated habitats such as Bökevik Bay and Kilviken Bay, access to shelter may significantly reduce the potency of predation (Berglund \& Bengtsson 1981). Since the high production of food organisms in shallow water probably will further reduce exploitation competition, interference competition is likely to be of greater importance. Thus, the habitat niche is predicted to be of greater importance for the segregation of coexisting small-sized predators in shallow water. These organisms can survive the physical stresses in the littoral. However, they are of course susceptible to biotic mortality agents, such as predation by larger fishes. Predators such as weevers, bullheads, larger flatfish and gadoids are more numerous in deeper water. The large numbers of juvenile gobiids leaving the littoral in autumn and the low numbers of returning survivors arriving from deeper water in spring suggest that predation is one of the main causes of population reduction during winter.

\section{CONCLUSIONS}

We suggest that the epibenthic community studied is strongly influenced by intra-guild predation close inshore during summer, and by predation from larger species not belonging to the guild in deeper water during winter. Competition for space and food undoubtedly is of importance for community structure, but normally is only of minor importance for population sizes of guild members. The opportunistic behaviour of the epibenthic predators make it possible for these species to exploit resources available when one or several of them temporarily is reduced in number or even absent. The brown shrimp and the 2 gobiid species have evolved adaptations to survive the rigours of the shallow water environment. However, their life history tactics may differ (Table 4), which may lower the probability of competitive exclusion.

Acknowledgements. We thank J. Gray, G. Gezelius and S. Ulfstrand for valuable comments on the manuscript, and A. Bengtsson and $\mathrm{C}$. Brodin for assistance in the experimental work. The work was conducted at Klubban Biological Station and we are grateful to $G$. Gezelius for providing excellent working conditions. The study was supported by grants from the Swedish Natural Science Council.

\section{LITERATURE CITED}

Berge, J. A., Hesthagen, I. H. (1981). Effects of epibenthic macropredators on community structure in an eutrophicated shallow water area, with special reference to food consumption by the common goby Pomatoschistus microps. Kieler Meeresforsch., Sonderh. 5: 462-470 
Berglund, A., Bengtsson, J. (1981). Biotic and abiotic factors determining the distribution of two prawn species: Palaemon adspersus and P. squilla. Oecologia (Berl.) 49: 300-304

Connell, J. (1975). Some mechanisms producing structure in natural communities: a model and evidence from field experiments. In: Cody, L., Diamond, J. M. (ed.) Ecology and evolution of communities. Belknap Press, Cambridge, p. $460-490$

Evans, S., Tallmark, B. (1979). A modified drop-net method for sampling mobile epifauna on marine shallow sandy bottoms. Holarct. Ecol. 2: 58-64

Evans, S., Tallmark, B. (1984). Seasonal dynamics of small vagile predators on a marine shallow soft bottom. Holarct. Ecol. 7: 138-148

Evans, S. (1983). Production, predation and food niche segregation in a marine shallow soft-battom community. Mar. Ecol. Prog. Ser. 10: 147-157

Evans, S. (1984). Energy budgets and predation impact of dominant epibenthic carnivores on a shallow soft bottom community at the Swedish west coast. Estuar. coast. Shelf Sci. 18: 651-673

Fonds, M., van Buurt, G. (1974). The influence of temperature and salinity on development and survival of goby eggs (Pisces, Gobiidae). Hydrobiol. Bull. Amsterdam 8: $110-116$

Fonds, M. (1973). Sand gobies in the Dutch Wadden Sea
(Promatoschistus, Gobiidae, Pisces). Neth. J. Sea Res. 6: $417-478$

Fouda, M. M., Miller, P. J. (1981). Age and growth of the common goby, Pomatoschistus microps, on the south coast of England. Estuar. coast. Shelf Sci. 12: 121-129

Hesthagen, I. (1977). Migrations, breeding, and growth in Pomatoschistus minutus (Pallas) (Pisces, Gobiidae) in Oslofjorden, Norway, Sarsia 63: 17-26

Jones, D., Miller, P. J. (1966). Seasonal migrations of the common goby Pomatoschistus microps (Krøyer), in Morecambe Bay and elsewhere. Hydrobiologia 27: 515-528

McArthur, R., Levins, R. (1967). The limiting similarity, convergence, and divergence of coexisting species. Am. Nat. 101: $377-385$

Quammen, M. L. (1984). Predation by shorebirds, fish, and crabs on invertebrates in intertidal mudflats: an experimental test. Ecology 65: 529-537

Muus, B. (1967). The fauna of Danish estuaries and lagoons. Meddr Danm. Fisk.-og Havunders. N. S. 5: 1-316

Schoener, T, W. (1974a). Resource partitioning in ecological communities. Science 185: 27-39

Swedmark, M. (1957). Variation de la croissance et de la taille dans differentes populations du teleosteen Gobius minutus. Coll. Int. Biol. Mar. Stat. Roscoff. l'Anée Biol. 3: $163-170$

This paper was presented by Professor J. Gray; it was accepted for printing on March 20, 1985 


\title{
Species abundance data from fouling communities conform to the gamma distribution
}

\author{
Günter H. Schmidt ${ }^{1}$ \& David J. Garbutt ${ }^{2}$ \\ Departments of ${ }^{1}$ Pure and Applied Zoology, and ${ }^{2}$ Applied Statistics, University of Reading, Whiteknights, \\ Reading RG6 2AJ, United Kingdom
}

\begin{abstract}
The gamma distribution successfully fitted 128 of 136 sets of species abundance data (\% cover) from a fouling study. In contrast to the more widely used log-normal, which always has an expected mode, the great flexibility of the gamma allows it to assymptote to the frequency (y) axis and therefore to satisfactorily describe the deeply concave shape of the observed abundance curves.
\end{abstract}

\section{INTRODUCTION}

Diversity statistics based upon 2 resource-apportioning models - log-normal and log-series distributions have recently been criticised for their lack of correspondence to species abundance distributions of marine invertebrate communities, as neither the log-normal nor the log-series satisfactority describe the deeply concave shape of the dominance-diversity curves of many species assemblages (Hughes 1984). Hughes (1984) introduced a multiple-parameter model which simulates recognized features of community dynamics and yields curves similar in shape to those derived from data of natural communities, but the practical applications of the model are less apparent. In particular, when information is available only on numbers of individuals, or percentage of substratum covered, the advantage of the currently employed theoretical distributions for summarising species frequency data is apparent (Ross 1980, Vandermeer 1981). The log-series distribution is a discrete distribution and applicable when counts of numbers of species with a given number of individuals are considered. A continuous distribution, however, is the appropriate model when species abundance data is recorded in continuous form, e.g. area covered (\%) by sessile fouling organisms, as in the present study. The log-normal is the most frequently used continuous distribution in benthic ecology (Hughes 1984), although alternative models are available, e.g. the gamma distribution (Ross 1980).

A theoretical basis for various descriptive uses of gamma distributions in statistical ecology, including the use as species abundance distributions, is given by Dennis \& Patil (1984). An advantage of the gamma over the log-normal is that it is flexible enough to describe a variety of data sets (Fig. 1; McCullagh \& Nelder 1983). The form may be unimodel and skewed to the right (Fig. 1c \& 1d), or asymptote to 0 (Fig. 1a). In contrast, the log-normal always has a mode between 0 and $\infty$ (McCullagh \& Nelder 1983). Hence, if species frequency curves are highly concave (Hughes 1984) they may approximate to gamma rather than log-normal. Gamma is a widely used model in community ecology (Ross 1980, Dennis \& Patil 1984); in the present paper it
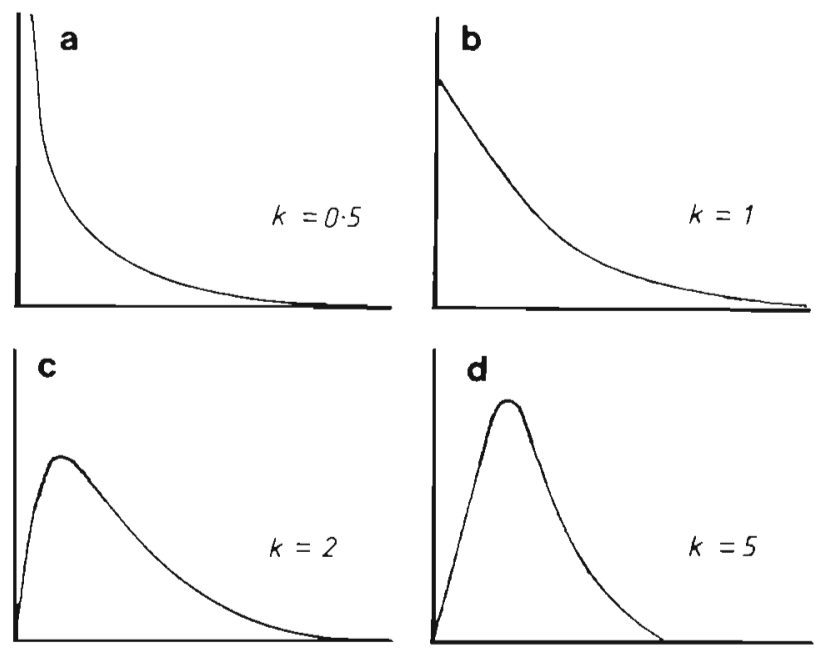

Fig. 1. The gamma distribution is highly flexible (forms $a, b, c$, $d)$; the parameter $\mathrm{k}$ determines the shape of distribution (the mean in a to $d$ is kept constant at 1). All distributions are positively skewed. A mode with zero at the origin is found only if $\mathrm{k}>1$. (After McCullagh \& Nelder 1983) 
is fitted to data collected from a fouling study (cf. Schmidt \& Warner 1984).

\section{MATERIALS AND METHODS}

Black perspex panels, $0.25 \times 0.25 \mathrm{~m}$ square and $5 \mathrm{~mm}$ thick, were attached to steel frames and sub- merged at a depth of ca $1 \mathrm{~m}$ in Langstone Harbour, Hampshire, UK. Fifty panels (25 vertical, 25 horizontal) were submerged on 12 Dec 1979 ('Winter series'), and 16 (8 vertical, 8 horizontal) on 1 Aug 1980 ('Summer series'); they were collected at monthly intervals until 16 Dec 1982 (for dates see Table 1). A further 23 panels were employed for 'caging experiments' (Schmidt \&

Table 1. Frequency abundance data (\% cover) were fitted to gamma distributions and the goodness of fit tested by means of $\chi^{2}$. Degrees of freedom given in brackets. Panels were submerged 12 Dec 1979 and collected on dates shown. The table shows a representative sample from a total set of 136 (available from the first author on request)

\begin{tabular}{|c|c|c|c|c|c|c|}
\hline \multirow[t]{3}{*}{ Date } & \multicolumn{2}{|c|}{ Vertical panels } & \multicolumn{4}{|c|}{ Horizontal panels } \\
\hline & & & & & & \\
\hline & $\underset{\text { fit }}{\text { Gamma }}$ & $\begin{array}{c}\text { No. of } \\
\text { species }\end{array}$ & $\begin{array}{c}\text { Gamma } \\
\text { fit }\end{array}$ & $\begin{array}{l}\text { No. of } \\
\text { species }\end{array}$ & $\underset{\text { fit }}{\text { Gamma }}$ & $\begin{array}{l}\text { No. of } \\
\text { species }\end{array}$ \\
\hline \multicolumn{7}{|l|}{1980} \\
\hline \multirow{3}{*}{$\begin{array}{rl}\text { May } 1 & 1 \\
& \end{array}$} & & & 0.39 (2) & 6 & & \\
\hline & $3.21 \quad(4)$ & 14 & $1.11(5)$ & 13 & & \\
\hline & 2.20 & 12 & & & & \\
\hline \multirow[t]{2}{*}{ Jun 27} & $1.02(5)$ & 15 & $5.64 \quad(4)$ & 12 & $0.38 \quad(2)$ & 6 \\
\hline & $3.02(6)$ & 14 & & & & \\
\hline \multirow[t]{2}{*}{ Jul 25} & $7.53 \quad(4)$ & 16 & $11.99(6)$ & 15 & $0.73 \quad(2)$ & 10 \\
\hline & 7.61 (4) & 16 & & & & \\
\hline \multirow[t]{2}{*}{ Aug 22} & $8.66(5)$ & 17 & $6.32(5)$ & 17 & 2.29 (3) & 9 \\
\hline & $6.44(2)^{\circ}$ & 17 & & & & \\
\hline \multirow[t]{2}{*}{ Oct 2} & $7.12(7)$ & 26 & $6.92(6)$ & 19 & $1.29(3)$ & 10 \\
\hline & 3.35 (7) & 24 & & & & \\
\hline \multirow[t]{2}{*}{ Oct 31} & $8.96(4)$ & 24 & $13.38(7)$ & 26 & $6.81(4)$ & 10 \\
\hline & 7.56 (7) & 23 & & & & \\
\hline \multirow[t]{2}{*}{ Nov 28} & $4.20 \quad(3)$ & 22 & $8.25 \quad(8)$ & 29 & $6.39(3)$ & 15 \\
\hline & $4.07 \quad(6)$ & 23 & & & & \\
\hline \multicolumn{7}{|l|}{1981} \\
\hline \multirow[t]{2}{*}{$\operatorname{Jan} 14$} & 0.41 (4) & 22 & $1.01 \quad(5)$ & 24 & $1.03(1)$ & 12 \\
\hline & $9.57(6)$ & 21 & & & & \\
\hline \multirow[t]{2}{*}{ Feb 10} & $5.26(5)$ & 25 & $14.35(\bar{p})^{\bullet}$ & 23 & 2.43 (3) & 13 \\
\hline & $2.77(6)$ & 23 & & & & \\
\hline \multirow[t]{2}{*}{ Mar 11} & $2.21 \quad(5)$ & 21 & $5.94 \quad(5)$ & 20 & $1.27 \quad(2)$ & 12 \\
\hline & $2.79(6)$ & 22 & & & & \\
\hline \multirow[t]{2}{*}{ Apr 8} & 7.85 (6) & 21 & $1.86(5)$ & 18 & 3.43 (4) & 16 \\
\hline & $6.63 \quad(5)$ & 19 & & & & \\
\hline \multirow[t]{2}{*}{ May 5} & $5.39(4)$ & 19 & $5.56 \quad(5)$ & 18 & 2.58 (3) & 9 \\
\hline & 3.16 (4) & 19 & & & & \\
\hline \multirow[t]{2}{*}{ Jun 3} & $14.83(7)^{\circ}$ & 19 & 5.49 (4) & 15 & $2.14 \quad(4)$ & 8 \\
\hline & $8.03(4)$ & 17 & & & & \\
\hline \multirow[t]{2}{*}{ Jul 1} & 8.82 (5) & 24 & $8.84 \quad(6)$ & 23 & $2.64 \quad(4)$ & 15 \\
\hline & $7.60(6)$ & 19 & & & & \\
\hline \multirow[t]{2}{*}{ Jul 30} & $4.94 \quad(7)$ & 24 & $6.09(5)$ & 18 & $1.98 \quad(5)$ & 10 \\
\hline & 0.80 & 17 & & & & \\
\hline \multirow[t]{2}{*}{ Aug 27} & $4.40 \quad(6)$ & 24 & $5.04 \quad(7)$ & 25 & $2.34 \quad(5)$ & 11 \\
\hline & 8.63 (6) & 24 & & & & \\
\hline \multirow[t]{2}{*}{ Oct 7} & $6.34(7)$ & 22 & $3.06(7)$ & 23 & $1.98 \quad(5)$ & 16 \\
\hline & 1.53 (4) & 23 & & & & \\
\hline \multirow[t]{2}{*}{ Nov 10} & $15.48(8)$ & 22 & $7.26(6)$ & 21 & $1.56 \quad(5)$ & 13 \\
\hline & $18.91(9)^{\circ}$ & 20 & & & & \\
\hline $\operatorname{Dec} 16$ & 13.01 (8) & 21 & $9.67 \quad(6)$ & 23 & $4.46 \quad(6)$ & 21 \\
\hline & $9.82(8)$ & 18 & & & & \\
\hline & $9.56(6)$ & 20 & & & & \\
\hline & $6.79(7)$ & 19 & & & & \\
\hline
\end{tabular}




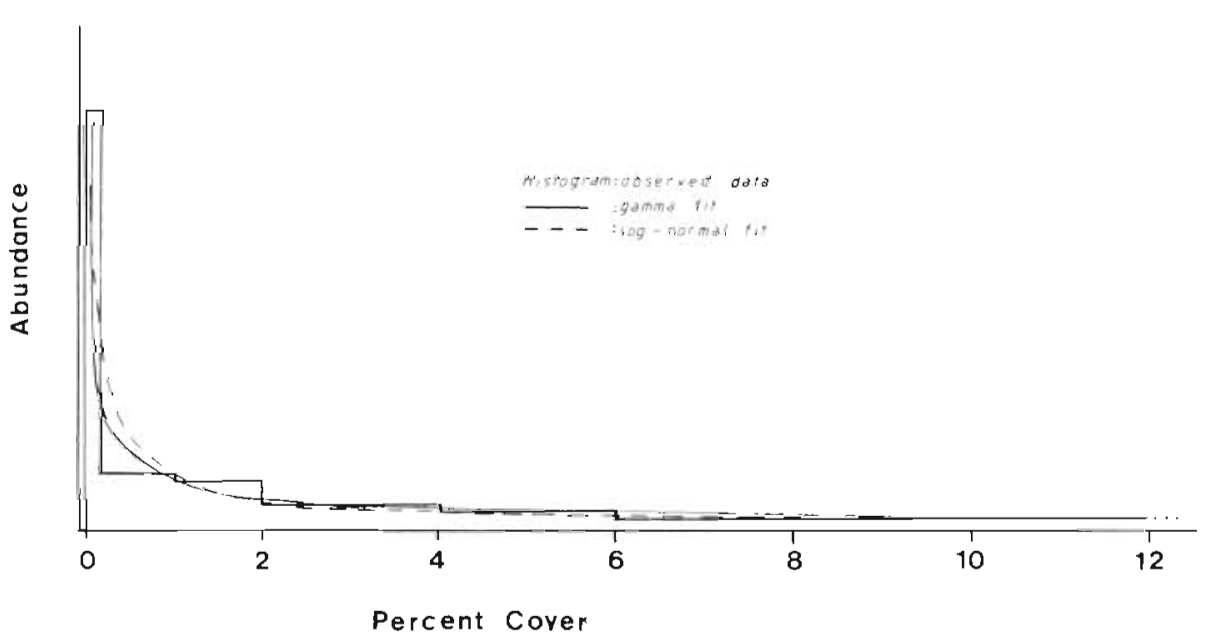

Fig. 2. Species abundance distribution for a fouling community which had developed on a $25 \times 25 \mathrm{~cm}$ panel over a period of 5.5 mo. Gamma and log-normal were fitted to the data using the method of maximum likelihood and tested for goodness of fit by means of $\chi^{2}$. The distributions were similar over much of their range but differed in the extreme left part: only gamma can assymptote to the frequency $(y)$ axis and follow the deeply concave shape of the observed data while log-normal has an expected mode. Gamma therefore yields a better $\chi^{2}$ value than log-normal (even though both fit statistically as the mode of the log-normal remains undetected by the sampling method employed): $\chi^{2}$ values - gamma: 1.1 on 4 d.f.; $\log$-normal: 3.68 on 4 d.f.

Warner 1984). The percentage area covered by each sessile species was determined by the line intersection method (Schmidt \& Warner 1984). When a species was present, but not sampled by any intersection point, it was arbitrarily assigned a cover value of $0.1 \%$. The species abundance data thus obtained were fitted to gamma (and log-normal for the data shown in Fig. 2) and tested for goodness of fit $\left(\chi^{2}\right)$ using the method of maximum likelihood (Ross 1980). 'Winter' panels collected prior to May 1980 and some horizontal upper surfaces carried too few species for meaningful statistical analysis.

\section{RESULTS AND DISCUSSION}

A total of 136 data sets were fitted to gamma; 128 of them statistically conformed to the distribution (tested at the $5 \%$ level, Table 1). A graphical representation of 1 set of data, with expected values also for log-normal distribution, is given in Fig. 2. The concave shape of the frequency curve is due to the relatively large number of species which occupied less than $1 \%$ of the panel area. The mode of the fitted log-normal in the first octave is not detected by our method as the $<0.15$ octave cannot be subdivided any further. Consequently, only the right hand side of the expected lognormal distribution is exposed, while the left side remains unsampled. This is a recognised property of sampling from a log-normal distribution when the sample size is small (Vandermeer 1981). However, although both models fit the data statistically, only the gamma which does not assume a mode that is un- detected can assymptote on the frequency $(y)$ axis (Fig. 1), following the deeply concave form of the observed species frequency data. It therefore yields a better $\chi^{2}$ value than log-normal. Gamma may also provide a valid model for other species abundance distributions which are highly concave and lack a mode (Hughes 1984). While the theoretical basis for the gamma may be complex (Dennis \& Patil 1984, Hughes 1984), its application in diversity statistics is of practical value, forming a basis for comparison of different communities or experimental treatments; diversity indices may be calculated from the fitted gamma distributions (Ross 1980, Schmidt \& Warner 1984) and further analysed by ANOVA (Kempton \& Taylor 1976). The present analysis was restricted to data given in continuous form; for counts of numbers of individuals the discrete negative binomial, which includes the logseries as a special case and is characterised by similar flexibility as the gamma (Ross 1980), may provide a satisfactory model.

Acknowlegdements. We thank Dr. G. F. Warner for encouragement and critical reading of the manuscript, and the Ministry of Defence (Navy) Exposure Trials Station (ETS), Portsmouth, for use of facilities and assistance with the field work. The study was carried out during the tenure of a Postgraduate Studentship (G.H.S.) awarded by the University of Reading.

\section{LITERATURE CITED}

Dennis, B., Patil, G. P. (1984). The gamma distribution and weighted multimodel gamma distributions as models of population abundance. Math. Biosc. 68: 187-121 
Hughes, R. G. (1984). A model of the structure and dynamics of benthic marine invertebrate communities. Mar Ecol. Prog. Ser. 15: 1-11

Kempton, R. A., Taylor, L. R. (1976). Models and statistics for species diversity. Nature, Lond. 262: 818-820

McCullagh, D., Nelder, J. A. (1983). Generalised linear models. Chapman \& Häll, London
Ross, G. J. S. (1980). MLP (Maximum Likelihood Program). Rothamstead Experimental Station, Harpenden, U.K.

Schmidt, G. H., Warner, G. F. (1984). Effects of caging on the development of a sessile epifaunal community. Mar. Ecol. Prog. Ser. 15: 251-263

Vandermeer, J. (1981). Elementary mathematical ecology. John Wiley \& Sons, Chichester

This paper was submitted to the editor; it was accepted for printing on March 23, 1985 


\title{
Mortality and avoidance of competitive overgrowth in encrusting Bryozoa
}

\author{
John A. Rubin* \\ Department of Biological Sciences, Plymouth Polytechnic, Drake Circus, Plymouth PL4 8AA, United Kingdom
}

\begin{abstract}
Forty-five species of sessile animals, including 32 species of cyclostome and cheilostome bryozoans, settled on experimental panels over a 1 yr period. Colonies were readily overgrown by tubes of the serpulid Pomatoceros triqueter (L.) which became the dominant species on the panel community. However, a number of bryozoan species avoided competitive exclusion by settling preferentially or by growing epizoically onto the tubes which were, therefore, acting as spatial refuges from overgrowth by the serpulid. Since bryozoans are inferior interference spatial competitors but are known to have greater longevity than $P$. triqueter, vegetative growth of the surviving colonies and subsequent pre-emptive exploitative competition are probably the main processes which give rise to the replacement of the serpulid to produce the bryozoan-dominated communities on nearby boulders.
\end{abstract}

\section{INTRODUCTION}

Bryozoa are one of the predominant taxa in a variety of sublittoral epibenthic environments, including the undersides of foliaceous corals (e.g. Jackson 1979, Palumbi \& Jackson 1982, Winston \& Jackson 1984), rock faces (Castric 1974, Keough \& Downes 1982), shells (Harmelin 1977, Kay \& Keough 1981), boulders (Osman 1977, Rubin 1982) and artificial pilings (Lichtschein de Bastida \& Bastida 1980, Kay \& Keough 1981). Their predominance, together with other colonial taxa, over solitary groups is believed to be due to their ability to grow vegetatively: this, in turn, enables them to be superior overgrowth interference competitors since, in their expansion, they occlude the feeding and respiratory orifices of solitary species (Jackson 1977a, Keough 1984). They may also be superior pre-emptive exploitative competitors (sensu Schoener 1983) since, having occupied space on the primary substratum, they are able to prevent its occupation by other species through growth (Karlson 1978, Sebens in press) or larval recruitment (e.g. Standing 1976, Sutherland 1978, Day \& Osman 1982).

The community on the underside of boulders in the shallow sublittoral off southwest England is dominated by bryozoans, particularly cheilostomes (Rubin 1982).

\footnotetext{
- Present address: 20 Leyford Close, Wembury, Plymouth PL9
} OHX, United Kingdom whereas artificial panels which were submerged in a similar environment off northwest France for up to $3 \mathrm{yr}$ were dominated by the solitary serpulid Pomatoceros triqueter (Castric 1974). This species rarely occupies $>5 \%$ of the space on the undersides of the boulders.

In this paper I describe the outcome of spatial encounters between Pomatoceros triqueter and bryozoans on artificial panels submerged in the vicinity of the boulders. I also report on growth and larval settlement strategies employed by some bryozoan species to avoid overgrowth mortality of very young colonies and discuss these in the context of the roles of interference and exploitative competition in structuring the boulder community.

\section{MATERIAIS, METHODS AND STUDY SITE}

Forty-eight $150 \times 150 \times 4 \mathrm{~mm}$ black perspex panels were submerged on 10 Feb 1981. The panel frame consisted of a cast-iron single bed with the springs removed. The panels were bolted onto metal straps which were themselves bolted onto the frame. This remained in a horizontal position.

Four panels, selected by using random number tables, were collected using SCUBA on 9 separate occasions over a 1 yr period. These panels were placed in $5 \%$ neutralised seawater formaldehyde until they could be examined under the stereo-microscope for 
identification and counting of individuals; each colony was scored as 1 individual. Percent cover was determined by superimposing an acetate sheet with $15 \times 15$ $=225$ equidistant points marked onto it, such that a margin $12 \mathrm{~mm}$ wide was not sampled around the periphery of each panel, thereby avoiding possible edge effects.

R-type cluster analysis was carried out on the frequency data matrix, in order to group species quantitatively with a similar pattern of occurrence over the duration of the experiment. This was carried out using the CLUSTAN program (Wishart 1978). The technique followed was that of Field et al. (1982): raw data were root-root transformed and standardised, and the similarity index used was the Bray-Curtis coefficient (Bray \& Curtis 1957). However, unlike Field et al., Principal Components Analysis was used in the ordination, the number of species was not reduced and the singlelinkage clustering method was followed.

The site chosen for submergence of the panel frame was $50 \mathrm{~m}$ to the south of Plymouth Breakwater, outside Plymouth Sound in southwest England (map ref $50^{\circ}$ $\left.21^{\prime} \mathrm{N}, 04^{\circ} 08^{\prime} \mathrm{W}\right)$ at a depth of $8 \mathrm{~m}$. The frame was placed $<1 \mathrm{~m}$ away from the base of the limestone blocks of which the Breakwater is composed. It rested on a substratum of sand and $10 \mathrm{~m}$ away from an accumulation of boulders which were up to $50 \mathrm{~cm}$ long. These acted as a probable source for colonization of panels, since the larval period of many bryozoans is short (Hayward \& Ryland 1979).

\section{RESULTS}

During the early months of submergence of the panels, colonization occurred by a number of species belonging to both solitary and colonial taxa, including spirorbids, a few Pomatoceros triqueter and cyclostome and cheilostome bryozoans. In July 1981 there was a massive spatfall of $P$. triqueter; subsequently these overgrew all other species which they encountered on the primary substratum through distal and lateral expansion of their tubes. The species overgrown consisted predominantly of cyclostome bryozoans (Fig. $1 \&$ 2), spirorbids and Anomia ephippium L. Overgrowth mortality of $P$. triqueter through occlusion of the orifice by bryozoans was never observed. Tubulipora liliacea (Pallas) suffered particularly high mortality as a result of overgrowth by $P$. triqueter (Fig. 2). Crowding by the serpulid also had an effect on some of the colonies which survived: these exhibited elongate and separate zooecia extending away from the panel surface (Fig. 3). Some cheilostome colonies which had already established were able to escape overgrowth mortality by growing epizoically onto tubes of neighbouring $P$. triqueter (Fig. 4).

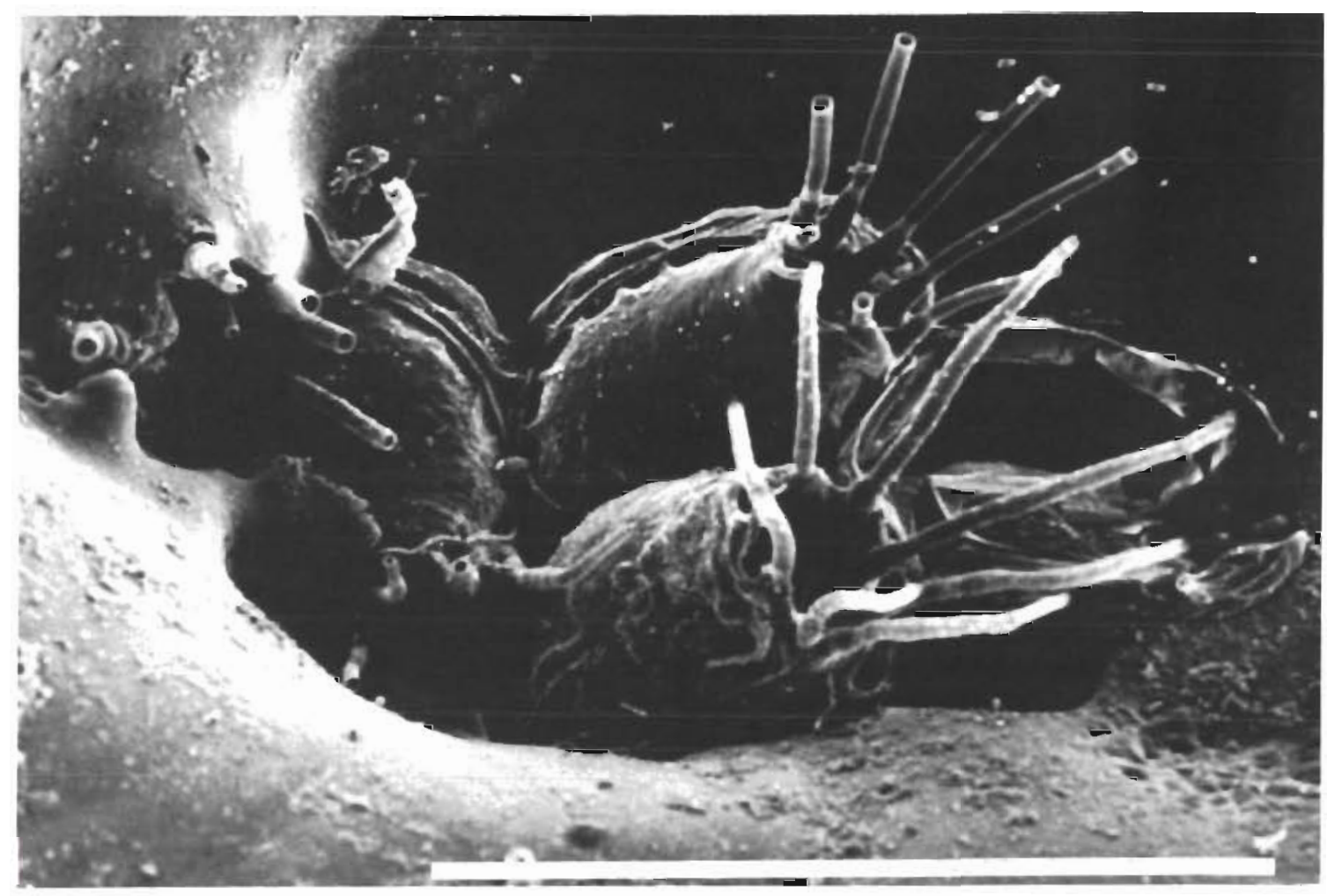

Fig. 1. Escharoides coccinea. Colony partly overgrown by Pomatoceros triqueter. Scale bar $=100 \mu \mathrm{m}$ 
Fig. 2. Tubulipora liliacea. Zooecia emerging from the side of a Pomatoceros triqueter tube. Rest of colony has been overgrown. Scale bar $=100 \mu \mathrm{m}$

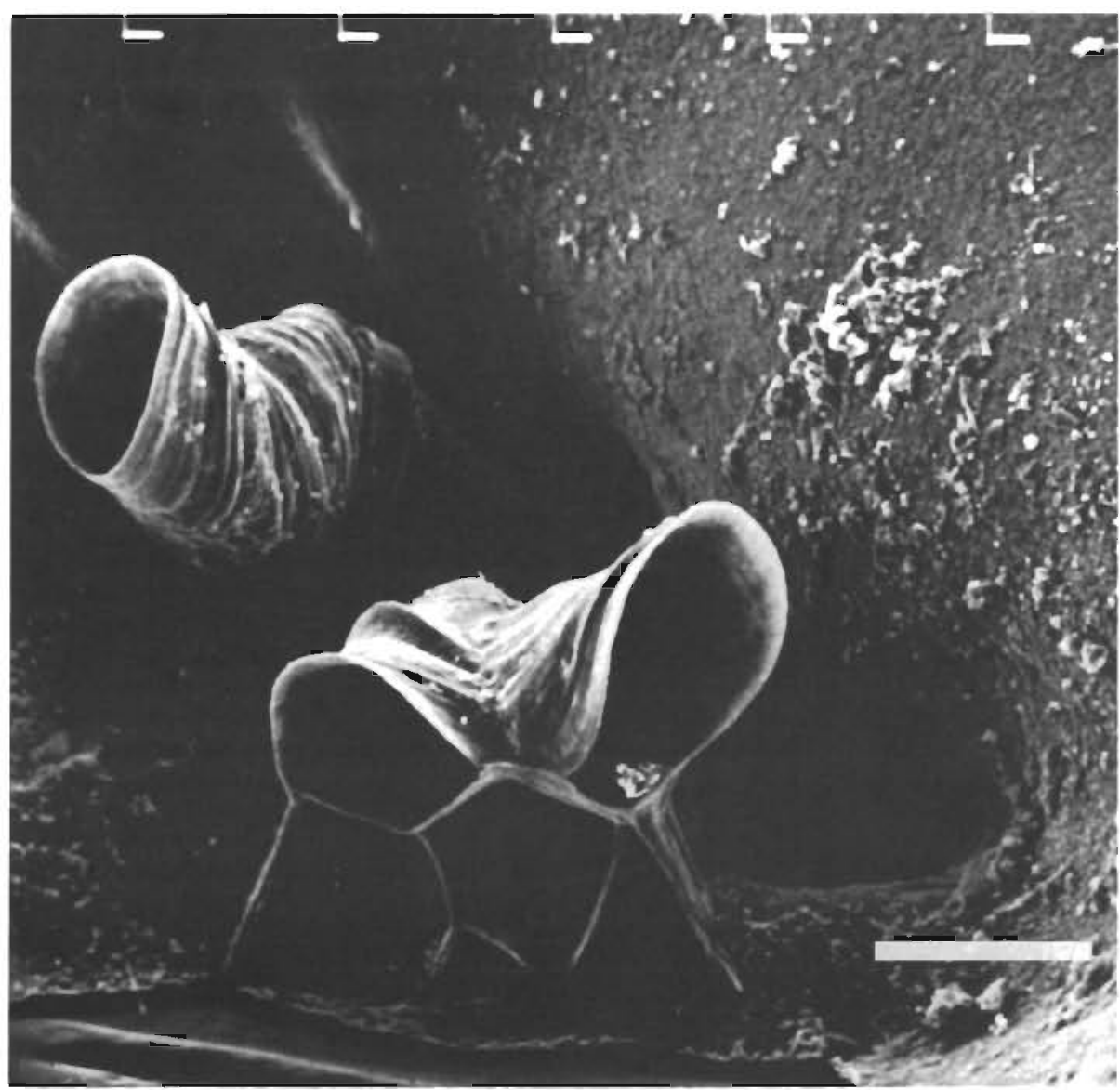

Some cheilostomes were also able to avoid competitive overgrowth by settling predominantly or exclusively on the tubes, although away from the apex (Fig. $5 \& 6$ ). Table 1 gives the results of a $\chi^{2}$ goodnessof-fit which tests the null hypothesis that there was no difference between the observed and expected frequencies of very young colonies consisting of 1 or 2 zooids (ancestrula and first peri-ancestrula) occuring on the Pomatoceros triqueter tubes, i.e. that these young colonies were derived from larvae which had settled randomly on the panels. This null hypothesis was tested for each of the 9 most abundant cheilostome species on the 8 panels collected on 15 Sept 1981 and 31 Oct 1981. These 2 dates were chosen since they covered a period during which many cheilostome larvae were settling and the percentage cover of $P$. triqueter was fairly high (mean $=32.56)$. Since cheilostome larvae also colonized both solitary species (other than $P$. triqueter) and Electra pilosa (L.), the latter were regarded as substrata which, together with bare panel

Table 1. Number of colonies consisting of 1 or 2 zooids for the 9 commonest cheilostome species on panels collected on 15 Sep 1981 and 31 Oct 1981

\begin{tabular}{|lccrrrr|}
\hline \multicolumn{1}{c}{ Species } & $\begin{array}{c}\text { Total no. } \\
\text { colonies }\end{array}$ & $\begin{array}{c}\text { No. colonies on } \\
\text { P. triqueter tubes }\end{array}$ & $\%$ & $\chi^{2}$ & P \\
\hline Callopora rylandi & 26 & 26 & 100 & 46.22 & $<0.001$ & $<$ \\
Cauloramphus spiniferum & 124 & 118 & 95.16 & 188.37 & $<0.001$ & 3 \\
Celleporella hyalina & 94 & 25 & 26.60 & 3.61 & $>0.05$ & $<$ \\
Celleporina hassallii & 39 & 31 & 79.49 & 32.01 & $<0.001$ & 2 \\
Chorizopora brongniartii & 14 & 14 & 100 & 24.89 & $<0.001$ & 4 \\
Escharoides coccinea & 45 & 45 & 100 & 80.00 & $<0.001$ & 4 \\
Membraniporella nitida & 31 & 24 & 77.42 & 23.08 & $<0.001$ & 3 \\
Microporella ciliata & 72 & 32 & 44.44 & 2.23 & $>0.05$ & 5 \\
Schizomavella linearis & 104 & 79 & 75.96 & 72.08 & $<0.001$ & 2 \\
\hline
\end{tabular}




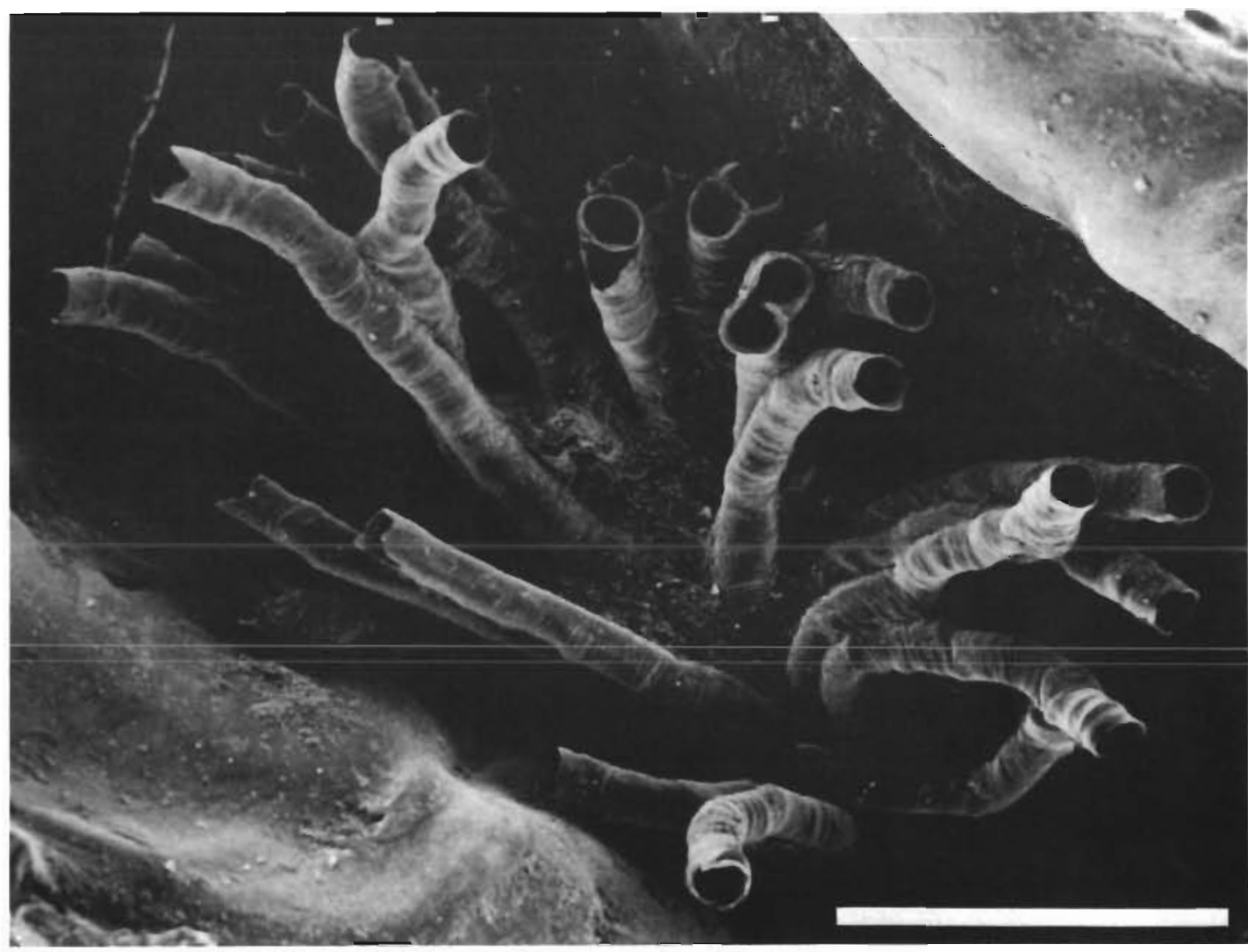

Fig. 3. Tubulipora liliacea. Colony, spatially restricted between 2 Pomatoceros triqueter tubes, has produced elongate zooecia. Scale bar $=1 \mathrm{~mm}$

surface, were available for colonization. The mean percentage cover of these areas collectively was 58.62 . The only areas which were not regarded as available for colonization by cheilostome larvae were other colonial species (mean percentage cover $=8.22$ ). These were mostly established cheilostomes. The expected frequencies for each species (the number of these very young colonies which would have occurred on the $P$. triqueter tubes if larval settlement had been random) were derived from the mean percentage cover values for the serpulid given above, with a correction to take account of the presence of these other colonial species.

Table 1 shows that this null hypothesis should be rejected for 7 of the 9 species, viz. their ancestrulae occurred preferentially on the sides of Pomatoceros triqueter tubes (all $\mathrm{P}<0.001$ ). In 3 of them - Callopora rylandi Bobin \& Prenant, Chorizopora brongniartii (Audouin) and Escharoides coccinea (Abildgaard) - all of the ancestrulae occurred on the tubes. If one also considers that 3 of the 9 species - C. rylandi, Cauloramphus spiniferum (Johnston) and Membraniporella nitida (Johnston) - were never recorded on younger poorly colonized panels also present on the frame at this time (Rubin unpubl.), it is possible to discern 5 patterns of settlement selection: (1) larvae settled exclusively on $P$. triqueter tubes and never on other available areas of mature panels nor on poorly colonized panels present at the time (C. rylandi); (2) larvae settled on $P$. triqueter tubes but also settled elsewhere on other available areas of mature panels and on poorly colonized panels present at the time (Celleporina hassallii [Johnston], Schizomavella linearis [Hassall]); (3) as (2) but no settlement on poorly colonized panels present at the time (C. spiniferum, $M$. nitida) $(4)$ as (2) but no settlement on other available areas of mature panels (C. brongniartii, E. coccinea); (5) settlement pattern not significantly different (P>0.05) from random (Celleporella hyalina [L.], Microporella hyalina [Pallas]). Settlement type (1) suggests a highly selective settlement behaviour pattern and type (5) little or no substratum selectivity.

The inverse (R-type) analysis of the data (Fig. 7) grouped together 35 species on the panels into a single, large cluster, whereas the more abundant species were more scattered on the ordination plot. In particular, Pomatoceros triqueter plotted away from the rest of the species in the community, while Celleporella hyalina, Escharoides coccinea and Microporella ciliata plotted together in a cluster intermediate in position between $P$. triqueter and the large cluster. 

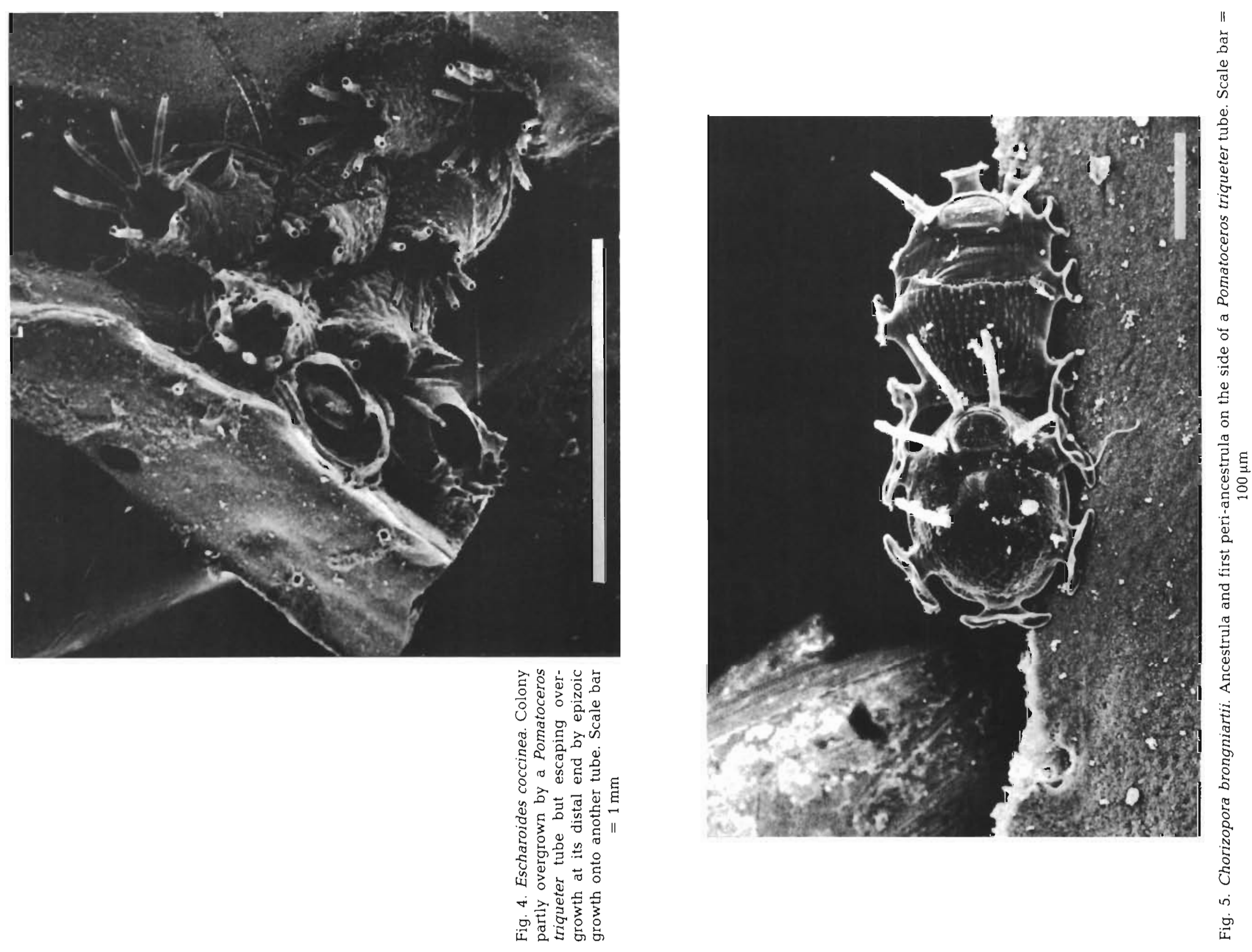


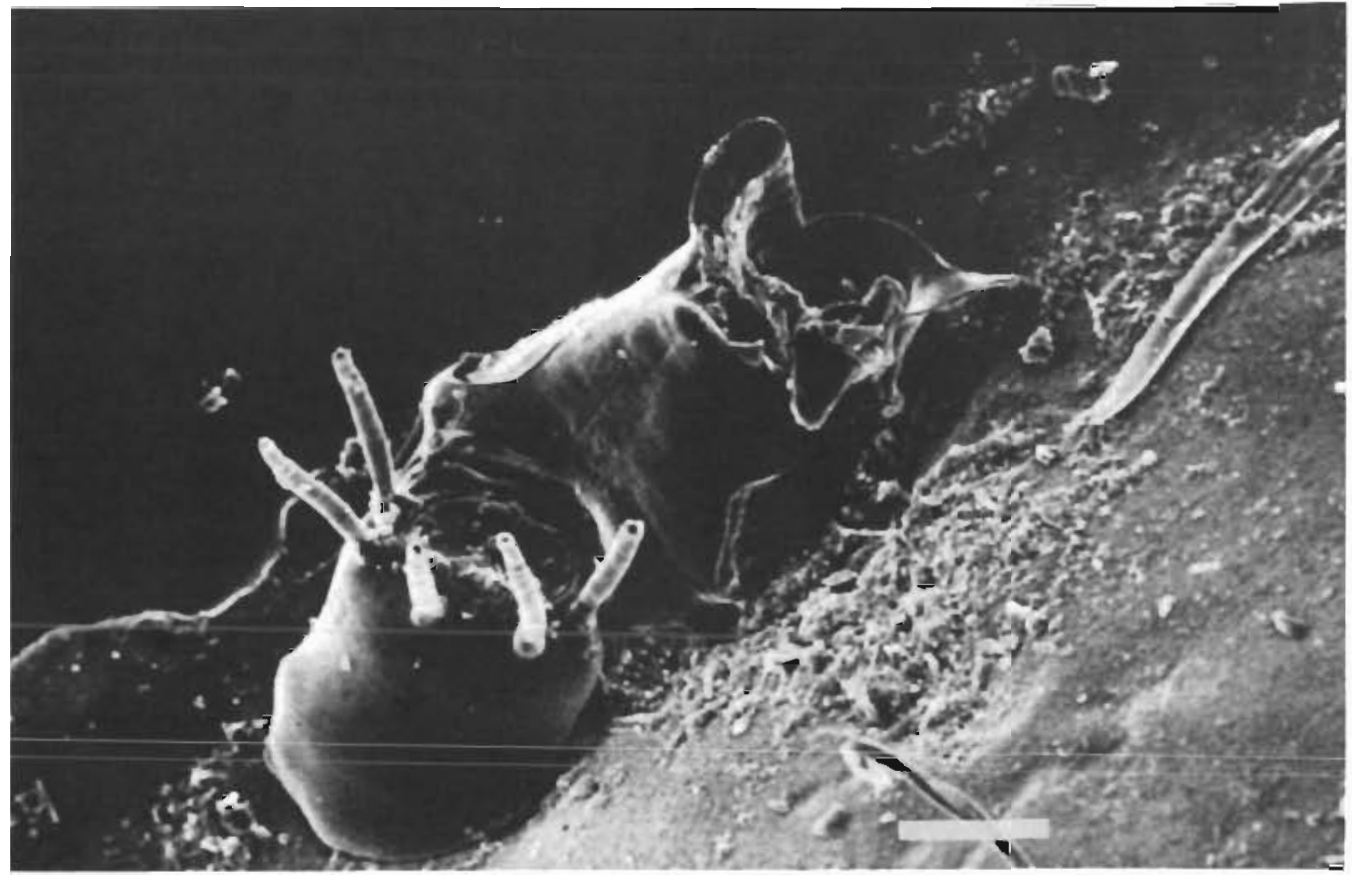

Fig. 6. Celleporina hassallii. Ancestrula and first peri-ancestrula on the side of a Pomatoceros triquetertube. Scale bar $=100 \mu \mathrm{m}$

Electra pilosa occurred as another outlier, reflecting its high abundance in the early stages of the experiment, in contrast to most of the other species.

\section{DISCUSSION}

\section{Role of different competitive mechanisms in structuring epibenthic communities}

Although a number of authors (e.g. Jackson $1977 \mathrm{~b}$, Scheltema et al. 1981, Schmidt 1983) have shown that aggregated, established solitary animals can inhibit

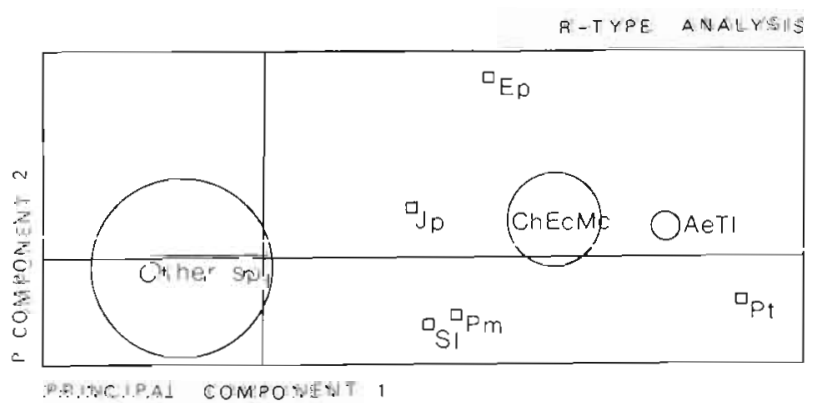

Fig. 7. Cluster diagram resulting from the R-type Principal Components Analysis of the frequency data matrix. Abbreviations: Ae Anomia ephippium, Ch Celleporella hyalina, Ec Escharoides coccinea, Ep Electra pilosa, Jp Janua pagenstecheri (Quatrefages), Mc Microporella ciliata, Pm Paralaeospira malardi Caullery \& Mesnil, Pt Pomatoceros trique-

ter, Sl Schizomavella linearis, T1 Tubulipora liliacea settlement by the larvae of colonial species - while others (e.g. Stebbing 1973, Jackson 1977a) have demonstrated that solitary animals, such as serpulids, are able to avoid overgrowth mortality by colonial species through vertically elevating the orifice away from the substratum - the overgrowth of cheilostome bryozoans by Pomatoceros triqueter is obviously a different phenomenon altogether. In particular, it contradicts the suggestion that solitary groups are inferior overgrowth interference competitors to colonial ones and shows that not all serpulids are ineffective space competitors (cf. Jackson 1977a), although small spirorbids may be (Keough 1984)

There are other examples in which solitary animals have been shown to be superior interference spatial competitors: Castric (1974) reported that Pomatoceros triqueter was capable of overgrowing thinly encrusting bryozoans, and E. Voigt (pers. comm.) showed that cheilostomes growing on hard substrata of Cretaceous age had been overgrown by serpulids while they were still alive. Furthermore, Haderlie (1974) demonstrated that barnacles were capable of displacing bryozoans by undercutting them, while Montanari \& Relini (1974) found that colonies of the ascidian Botryllus schlosseri fragmented when they came into contact with small, recently settled barnacles and serpulids.

If, as appears likely, the cheilostome-dominated community on the underside of nearby boulders is a later successional stage than the one on the panels, the problem arises of how a strong overgrowth spatial competitor can eventually be replaced by weaker ones. 
(Since there are occasional boulders which are almost entirely covered by Pomatoceros triqueter, it is unlikely that the difference between the 2 communities can be explained in terms of preferential larval settlement, with $P$. triqueter preferring panels and cheilostomes preferring boulders.) Although estimates of the longevity of $P$. triqueter in northern European waters vary from 18 mo (Føyn \& Gjøen 1954) to 30 mo (Castric 1983), many cheilostomes live longer than this (Eggleston 1972, Winston \& Jackson 1984), even though partial senescent mortality does occur in the latter (Jackson \& Winston 1981). In this paper 2 strategies for reducing the overgrowth mortality of cheilostomes by $P$. triqueter have been described, viz. epizoic growth onto neighbouring tubes (Fig. 4) and selective larval settlement onto the tubes (Table 1 ; Fig. 5 \& 6). Therefore it is likely that, by avoiding competitive exclusion in the early stages of community development, by having greater longevity, and by subsequently inhibiting further settlement of $P$. triqueter, cheilostomes are eventually able to replace the serpulid in the development of the community. In other words, it is the pre-emptive exploitative competitive ability of this group of colonial animals and not superior interference competitive ability which enables them to dominate in certain epibenthic communities.

Greene \& Schoener (1982) and Greene et al. (1983) also recognised the importance of longevity and of subsequent pre-emptive exploitative competition in structuring epibenthic communities on artificial panels, although they found that various species of solitary animal eventually became dominant through having greater longevity. All of these apparently contradictory results serve to underline the importance of having a detailed knowledge of the life-history characteristics of the participating species before making predictions or generalizations concerning the role of spatial interactions in structuring epibenthic communities.

The clustering together of Celleporella hyalina, Escharoides coccinea and Microporella ciliata on the ordination plot (Fig. 7) suggests that spatial competition between these cheilostomes, the most abundant on the panels, was not a major factor in structuring the panel community (although some interspecific overgrowth between them did occur). This is despite the fact that they have very different overgrowth competitive abilities (Rubin 1982), with E. coccinea being a very strong competitor and $M$. ciliata a weak one. $C$. hyalina is a particularly weak overgrowth competitor (Rubin unpubl.) and exists predominantly as an epiphyte (Hayward \& Ryland 1979). The plotting of Pomatoceros triqueter as an outlier in Fig. 7 reflects its numerical dominance throughout most of the period of panel submergence, very largely as a result of its formidable overgrowth competitive ability.

\section{Recruitment and location of spatial refuges by cheilostome larvae}

I suggest that, by selective epizoic settlement onto Pomatoceros triqueter tubes, cheilostome larvae were locating spatial refuges from overgrowth mortality of the very youngest zooids. Although it is known that larger colonies are able to suffer partial mortality without loss of the entire genet (Jackson 1977a, Jackson \& Winston 1981, Palumbi \& Jackson 1982), a characteristic of modular organisms in general (see Harper 1981 for review), mortality of even a very few zooids in the initial stages of colony growth would have a much more serious effect: the need to maintain the viability of the ancestrula may be particularly important since, if it were killed off, perhaps by overgrowth, translocation of nutrients across the growing colony would be seriously affected. D'Hondt (1976) found that, by killing off the ancestrula in very young colonies of Alcyonidium polyoum, further colony growth was inhibited. Furthermore in a number of species, including Celleporina hassallii and Schizomavella linearis, frontal budding commences directly above the ancestrula (Fig. 8; Schaaf 1974); presumably, therefore, mortality of the ancestrula would also inhibit this type of growth. Undoubtedly the statement by Silén $(1977$, p. 213) that the ancestrula has no special function in the life of the developed colony except constituting the primary or sometimes the only holdfast' requires qualification and it would be interesting to ascertain the minimum size which a colony needs to reach, beyond which mortality of the ancestrula would no longer inhibit growth.

While it has been recognised that small, isolated substrata can act as refuges for competitively subordinate species (Harmelin 1977, Jackson 1977b, Kay \& Keough 1981, Keough 1983), together with environments inimical to the growth of competitive dominants (Harmelin 1980), refuges in the form of microhabitats which can be located by larvae and which would, in turn, confer increased fitness on the adults by avoiding overgrowth mortality have been recognised by a number of authors. Larval settlement patterns designed to locate such refuges include: (1) aggregative settlement by competitively subordinate bryozoans (Buss 1981); (2) selective settlement by bryozoans onto live adult colonies of their own species (Gordon 1970); (3) selective settlement by species close to competitive subordinates (Buss 1979, Keen \& Neill 1980); (4) selective settlement by a subordinate species away from competitive dominants (Grosberg 1981, Sebens 1983); (5) selective epizoic settlement onto 


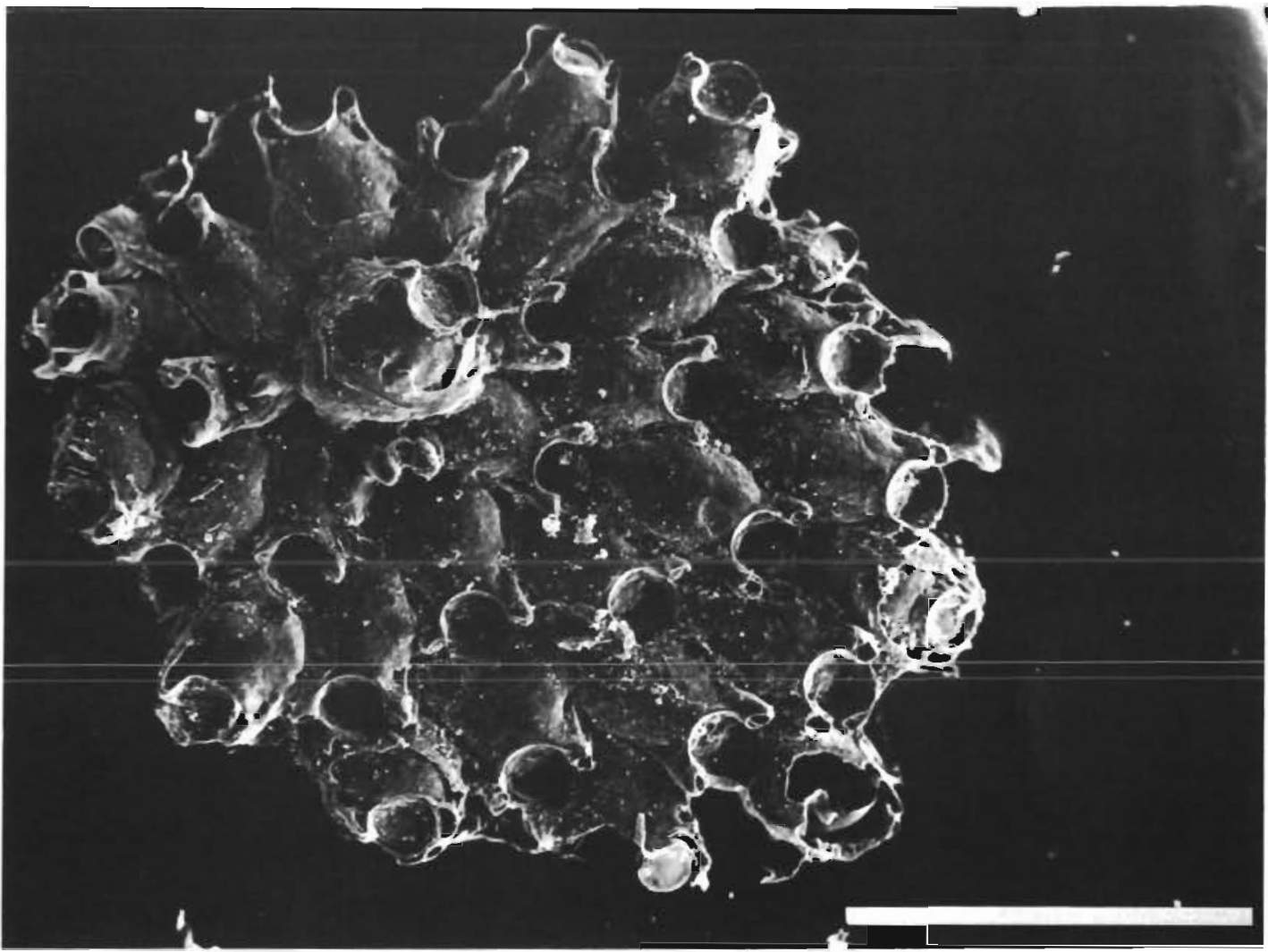

Fig. 8. Celleporina hassallii. Young colony with first frontally-budded zooid growing directly above the ancestrula. Scale bar $=$ $1 \mathrm{~mm}$

inert parts of a competitive dominant (this study). In addition, Young \& Chia (1981) have shown that larvae of competitively subordinate species can delay settlement when competitive dominants are present: this would increase the likehood of one of these types of refuge being located.

Acknowledgements. I thank Dr. A. R. D. Stebbing, Dr. G. F. Warner and L. Scott, as well as 2 anonymous reviewers, for their comments on an earlier version of the manuscript. This work was undertaken in partial fulfilment of a Ph. D. degree of the University of Reading, U.K., supervised by Drs G. F. Warner and J. M. Hinton.

\section{LITERATURE CITED}

Bray, J. R., Curtis, J. T. (1957). An ordination of the upland forest communities of Southern Wisconsin. Ecol. Monogr. 27: $325-349$

Buss, L. W. (1979). Habitat selection, directional growth and spatial refuges: why colonial animals have more hiding places. In: Larwood, G., Rosen, B. R. (eds.) Biology and systematics of colonial organisms. Academic Press, New York, p. 459-497

Buss, L. W. (1981). Group living, competition and the evolution of cooperation in a sessile invertebrate. Science 213: 1012-1014

Castric, A. (1974). Les peuplements sessiles du benthos rocheux de l'archipel de Glénan, Sud Bretagne: écologie descriptive et expérimentale. Unpubl. doctoral thesis, Université de Paris VI

Castric, A. (1983). Recrutement, croissance et longévité de Pomatoceros triqueter et de Pomatoceros lamarkii sur plaques expérimentales en Baie de Concarneau (Sud Finistère). Annls. Inst. océanogr. Paris 59: 69-91

Day, R. W., Osman, R. W. (1982). Predation by Patiria miniata (Asteroidea) on bryozoans: prey diversity may depend on the mechanism of succession. Oecologia (Berl.) 51: 300-309

Eggleston, D. (1972). Patterns of reproduction in the marine Ectoprocta of the Isle of Man. J. Nat. Hist. 6: 31-38

Field, J. G., Clarke, K. R., Warwick, R. M. (1982). A practical strategy for analysing multispecies distribution patterns. Mar. Ecol. Prog. Ser 8: 37-52

Føyn, B., Gjøen, I. (1954). Studies on the serpulid Pomatoceros triqueter L.: observations on the life history. Nyt. Mag. Zooi. 2: $73-\overline{8}$ i

Gordon, D. (1970). Reproductive ecology of some Northern New Zealand Bryozoa. J. Nat. Hist. 6: 31-38

Greene, C. H., Schoener, A. (1982). Succession on marine hard substrata: a fixed lottery. Oecologia (Berl.) 55: 289-297

Greene, C. H., Schoener, A., Corets, E. (1983). Succession on marine hasd substrata: the adaptive value of solitary and colonial strategies in temperate fouling communities. Mar. Ecol. Prog. Ser. 13: 121-129

Grosberg, R. K. (1981). Competitive ability influences habitat choice in marine invertebrates. Nature, Lond. 290: 700-702 
Haderlie, E. C. (1974). Growth rate, depth preference and ecological succession of some sessile marine invertebrates in Monterey Harbor. Veliger 17: 1-35

Harmelin, J.-G. (1977). Bryozoaires des îles d'Hyères: cryptofaune bryozoologique des valves vides de Pinna nobilis rencontrées dans les herbiers de Posidonies. Trav. Sci. Parc Natl. Port-Clos 3: 89-120

Harmelin, J.-G. (1980). Etablissement des communautés de substrats durs en milieu obscur Résultats préliminaires d'une expérience à long terme en Méditerranée. Memorie Biol. mar. Oceanogr. 10: 29-52

Harper, J. L. (1981). The concept of population in modular organisms. In: May, R. M. (ed.) Theoretical ecology. Blackwell, Oxford p. 53-77

Hayward, P. J., Ryland, J. S. (1979). British ascophoran bryozoans: synopses of the British fauna, Linn. Soc. Academic Press, London

Hondt, J.-L. d' (1976). Effets sur l'ablation de l'ancestrula ou de la première zooécie-fille sur le développement d'une jeune colonie du Bryozoaire ctenostome Alcyonidium polyoum (Hassall). Bull. Soc. zool. Fr. 101: 993-995

Jackson, J. B. C. (1977a). Competition on marine hard substrata: the adaptive significance of solitary and colonial strategies. Am. Nat. 111: 743-767

Jackson, J. B. C. (1977b). Habitat area, colonization and the development of epibenthic community structure. In: Keegan, B. F., O'Ceidigh, P., Boaden, P. J. S. (eds.) The biology of benthic organisms. Proc. 10th Europ. mar. Biol. Symp. Pergamon, Oxford, p. 349-358

Jackson, J. B. C. (1979). Overgrowth competition between encrusting cheilostome ectoprocts in a Jamaican cryptic reef environment. J. Anim. Ecol. 48: 805-823

Jackson, J. B. C., Winston, J. E. (1981). Modular growth and longevity in bryozoans. In: Larwood, G. P., Nielsen, C. (ed.) Recent and fossil Bryozoa. Olsen and Olsen, Fredensborg, p. 121-126

Karlson, R. (1978). Predation and space utilization patterns in a marine epifaunal community. J. exp. mar. Biol. Ecol. 31: 225-239

Kay, A. M., Keough, M. J. (1981). Occupation of patches in the epifaunal communities on pier pilings and the bivalve Pinna bicolor at Edithburgh, South Australia. Oecologia (Berl.) 48: 123-130

Keen, S. L., Neill, W. E. (1980). Spatial relationships and some structuring processes in benthic intertidal animal populations. J. exp. mar. Biol. Ecol. 45: 139-155

Keough, M. J. (1983). Patterns of recruitment of sessile invertebrates in two subtidal habitats. J. exp. mar. Biol. Ecol. 66: 213-245

Keough, M. J. (1984). Dynamics of the epifauna of the bivalve Pinna bicolor: interactions among recruitment, predation and competition. Ecology 65: 677-688.

Keough, M. J., Downes, B. J. (1982). Recruitment of marine invertebrates: the role of active larval choices and early mortality. Oecologia (Berl.) 54: 384-352

Lichtschein de Bastida, V., Bastida, R. (1980). Los briozoos incrustes de puertos argentinos. In: 5th Int. Congress on Marine Corrosion and Fouling, Garsi, Madrid, p. 371-390

Montanari, M., Relini, G. (1974). Osservazioni preliminari sull'accrescimento di Botryllus schlosseri su substrati artificiali immersi in mare. Memorie Biol. mar. Oceanogr. 4: 373-403

Osman, R. W. (1977). The establishment and development of a marine epifaunal community. Ecol. Monogr. 47: 37-63

Palumbi, S. R, Jackson, J. B. C. (1982). Ecology of cryptic coral reef communities II. Recovery from small disturbance events by encrusting Bryozoa: the influence of 'host' species and lesion size. J. exp. mar. Biol. Ecol. 64: 103-115

Rubin, J. A. (1982). The degree of intransitivity and its measurement in an assemblage of encrusting cheilostome Bryozoa. J. exp. mar. Biol. Ecol. 60: 119-128

Schaaf, A. (1974). Les modalités de la croissance et ses altérations chez quelques bryozoaires cheilostomes. Application à l'espèce Steginoporella rhodanica Buge et David, 1967. Trav. Lab. Géol. Univ. Lyon 60: 1-82

Scheltema, R. S., Williams, I. P., Shaw, M. A., Loudon, C. (1981). Gregarious settlement by the larvae of Hydroides dianthus (Polychaeta: Serpulidae). Mar. Ecol. Prog. Ser. 5: $69-74$

Schmidt, G. H. (1983). Studies on the development of fouling communities on experimental panels in Langstone Harbour. Unpubl. Ph. D. thesis, University of Reading, U.K.

Schoener, T. W. (1983). Field experiments on interspecific competition. Am. Nat. 122: 240-284

Sebens, K. P. (1983). The larval and juvenile ecology of Aplidium siderum Verrill. I. Substratum selection by benthic larvae. J. exp. mar. Biol. Ecol. 71: 73-89

Sebens, K. P. (in press). Spatial relationships among encrusting marine organisms in the New England subtidal. Ecology

Silén, L. (1977). Polymorphism. In: Woollacott, R. M., Zimmer, R. L. (ed.) Biology of Bryozoa. Academic Press, New York, p. $183-232$

Standing, J. D. (1976). Fouling community structure: effects of the hydroid Obelia dichotoma on larval recruitment. In: Mackie, G. O. (ed.) Coelenterate ecology and behaviour. Plenum Press, New York, p. 155-164

Stebbing, A. R. D. (1973). Competition for space between the epiphytes of Fucus serratus L. J. mar. biol. Ass. U.K. 53: $247-261$

Sutherland, J. P. (1983). Functional roles of Schizoporella and Styela in the fouling community at Beaufort, North Carolina. Ecology 59: 257-264

Winston, J. E., Jackson, J. B. C. (1984). Ecology of cryptic coral reef communities. IV. Community development and life histories of encrusting cheilostome Bryozoa. J. exp. mar. Biol. Ecol. 76: 1-24

Wishart, D. (1978). Clustan user manual, Program library unit. Univ. of Edinburgh, U.K.

Young, C. M., Chia, F. S. (1981). Laboratory evidence for the delay of larval settlement in response to a dominant competitor. Int. J. invertebr. Reprod. 3: 221-226 
